\title{
Original paper \\ Intrusive and deformation history of the Ševětín Pluton, Moldanubian Batholith: record of polyphase tectonic evolution of the Blanice Graben, Bohemian Massif
}

\author{
Jiří ZACHARIÁŠ ${ }^{*}$, Jakub TRUBAČ² \\ ${ }^{1}$ Institute of Geochemistry, Mineralogy and Mineral Resources, Faculty of Science, Charles University in Prague, Albertov 6, 12843 \\ Prague 2, Czech Republic; jiri.zacharias@natur.cuni.cz \\ ${ }^{2}$ Czech Geological Survey, Klárov 3, 11821 Prague 1, Czech Republic \\ * Corresponding author
}

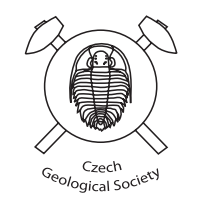

The Ševětín Pluton, located c. 15 km NNE of České Budějovice, is a small, isolated, petrologically and structurally complex intrusive body that is genetically related to the youngest intrusions of the Moldanubian Batholith. As documented in this study, its overall shape, internal magmatic fabric as well as brittle structures (dikes, veins, joints, faults) are, however, related to the formation and polyphase tectonic evolution of the Blanice Graben, an about $200 \mathrm{~km}$ long and 5-15 km wide NNE-SSW-trending, deep-seated fault zone that cuts across the Moldanubian Unit.

In total, one pre-intrusive and three syn- to post-intrusive tectonic phases have been distinguished. The oblique, NW-SE oriented compression controlled both the intrusion of the Ševětín biotite-muscovite granite and the early stage of its brittle deformation. Sigmoidal pattern of magnetic foliations in this pluton documents its mostly solid-state deformation during oblique sinistral movements on the main faults of the Blanice Graben. The subsequent strike-slip phase was characterized by E-W oriented subhorizontal extension and can be correlated with the intrusion of $c .270$ Ma old microgranodiorite dikes. The last extensional phase was associated with the formation of subeconomic $\mathrm{Pb}-\mathrm{Zn}-(\mathrm{Ag}$ ?) quartz-calcite veins at c. $265 \mathrm{Ma}$.

Keywords: Moldanubian Zone, Moldanubian Batholith, Blanice Graben, paleostress analysis, AMS study, Pb-Zn veins Received: 20 February 2014; accepted: 3 October 2014; handling editor: J. Žák

The online version of this article (doi: 10.3190/jgeosci.175) contains supplementary electronic material.

\section{Introduction}

Extensional tectonics associated with late-orogenic evolution of collisional orogens is often coupled with extensive crustal melting and subsequent granitic magma emplacement into the middle to upper crustal levels. Simultaneously, large-scale shear zones are formed in the continental crust to accommodate its stretching (e.g. Malavieille 1993; Faure 1995). At late stages of this scenario, shallow crustal levels are dominated by brittle tectonics and by formation tectonically-controlled sedimentary basins.

Granitic bodies emplaced in tectonically active zones can be used both as passive and active markers of crustal deformation, but also have the potential of dating these processes. Anisotropy of magnetic susceptibility (AMS) is a widely used method for analysis of cryptic magmatic to solid-state deformational fabrics in such granitoid rocks. Moreover, the paleostress orientation and stress ratio can be inferred from examining mode-I fractures (dikes, veins, joints), as well as from interpretation of striations (slickenlines) along fault planes.

This study focuses on the identification of tectonic regimes that controlled the evolution of central and southern parts of the c. $200 \mathrm{~km}$ long and NNE-SSWtrending Blanice Graben in the core of the Bohemian Massif. Its formation documents the final stages of orogenic collapse associated with the formation of linear Permo-Carboniferous sedimentary basins, as well as with repeated magmatic and hydrothermal activity. In all these aspects, the Blanice Graben resembles similar tectonic zones of Variscan Europe. Our goal was achieved through a detailed study of the magmatic and solid-state deformational fabrics of the Ševětín Pluton, a small intrusion genetically related to the Moldanubian Batholith.

\section{Regional setting}

Moldanubian Zone (Fig. 1a) represents a heterogeneous assemblage of medium- to high-grade metamorphic rocks, mainly paragneisses and migmatites, locally with calcareous, graphitic and metabasic intercalations as well as bodies of granulite, eclogite and serpentinite (e.g. Fiala et al. 1995). It is usually subdivided into the lower crustal/upper mantle Gföhl Unit with numerous occurrences of HP-HT granulite (e.g. Racek et al. 2006; Janoušek and 
Holub 2007; Franěk et al. 2011) and eclogite (e.g. Medaris et al. 2005) massifs and into the medium-pressure mid-crustal Drosendorf and Ostrong units (Dallmeyer et al. 1995; Franke 2000). Recent structural studies documented that many of the high-pressure lithologies within the Gföhl Unit represent vertical extrusions of lower crustal rocks (e.g. Finger et al. 2007; Franěk et al. 2011; Schulmann et al. 2014). The granulite-facies metamorphism occurred at about $340 \mathrm{Ma}$ (e.g. Friedl et al. 2011), followed by rapid exhumation to mid-crustal levels (c. 338-335 Ma) and subsequent nearly isobaric cooling through $\sim 300^{\circ} \mathrm{C}$ between c. $320-310 \mathrm{Ma}$ (e.g. Matte et al. 1985).

The Moldanubian Batholith (or South Bohemian; c. $6000 \mathrm{~km}^{2}$ ) is the largest Variscan magmatic complex in the Bohemian Massif. It has a horseshoe shape with western (Bavarian) and eastern (Moravo-Moldanubian) branches joining in the Waldviertel area (Austria). The eastern branch forms a NNE-SSW trending domal structure formed by gravity-driven diapiric upwelling of the metapelitic middle crust (Žák et al. 2011; Verner et al. 2014). The Moldanubian Batholith consists of three to four principal intrusive groups (mostly $\mathrm{S}$ and S/I types, rarely I-type; e.g. Holub et al. 1995; Klečka and Matějka 1996; Matějka and Janoušek 1998; Gerdes et al. 2000, 2003; Gerdes 2001; Finger et al. 2009; Breiter 2010), ranging in age from c. 330-323 Ma to c. 305-302 Ma (see, e.g., the review of Bankwitz et al. 2004).

The Blanice Graben (also called the Kouřim-BlaniceKaplice-Rödl fault zone; Fig. 1a) extends from Český Brod E of Prague to Linz in Austria. On a regional scale, it belongs to a set of conjugate sinistral (NE-SW; e.g. Vitis, Rödl, Diendorf) and dextral (NW-SE; e.g. Pfahl, Danube) shear zones in the southern part of the Bohemian Massif, which resulted from late Variscan $\mathrm{N}-\mathrm{S}$ oriented compression (Brandmayr et al. 1995).

The southernmost (Austrian) part of the Blanice Graben (also referred to as the Rödl shear zone) is a sinistral ductile shear zone with NE-SW-trending, steeply dipping foliation and subhorizontal stretching lineation. Synkinematic mylonitization was dated at around 288-281 Ma (Brandmayr et al. 1995; Ar-Ar method); however, these ages most probably only represent cooling below the muscovite blocking temperature. Paleostress analysis of brittle faults and fractures from the same zone documented their formation in the strike-slip regime under NW-SE and NE-SW oriented subhorizontal maximum principal stress direction $\left(\sigma_{1}\right)$ and minimum principal stress direction $\left(\sigma_{3}\right)$, respectively. The authors, however, suggested that the brittle deformation phase and related movements corresponded to Alpine tectonic reactivation of the Rödl shear zone at c. $170-180 \mathrm{Ma}$.
In the northern (Czech) part of the Rödl fault zone, Vrána and Bártek (2005) found indicators of sinistral displacement $\sim 17 \mathrm{~km}$ south of Kaplice. The early ductile phase of this deformation is constrained to $303 \pm 5 \mathrm{Ma}$ by Ar-Ar dating of hornblende from a quartz diorite porphyry dike (Vrána et al. 2005) that intruded synkinematically during the development of the mylonitic fabric in the fault/shear zone.

A late stage of tectonomagmatic activity in the Blanice Graben is indicated by the $270 \pm 2 \mathrm{Ma} \mathrm{Ar}-\mathrm{Ar}$ age of hornblende from a pyroxene microgranodiorite dike near Dehetník (Fig. 1a; Košler et al. 2001). The parental magma of this dike originated from mixing between remelted lower crustal (Moldanubian) rocks and primary magmas derived from an upper mantle source (Košler et al. 2001; Vrána and Janoušek 2006).

The tectonic activity along the faults of the Blanice Graben can also be inferred from the presence of several discontinuous occurrences (erosional relics) of Permo-Carboniferous (Gzhelian to Cisuralian; c. 300$275 \mathrm{Ma}$ ) sedimentary successions (Holub 2001). It is not clear whether these originally formed a continuous sedimentary basin. If so, then it was about $12 \mathrm{~km}$ wide and at least $130 \mathrm{~km}$ long. The main and late stages of sedimentation were accompanied by movements along the eastern faults of the Blanice Graben. This is indicated by: (i) the location of the axis of maximum subsidence close to the eastern margin of the Blanice Graben, (ii) the presence of proluvial conglomerates exclusively along the eastern marginal fault and (iii) the general dip of the strata to the $\mathrm{E}\left(10-40^{\circ}\right)$. The maximum thickness of the Permo-Carboniferous strata is at least $700-800 \mathrm{~m}$ in the northern (near Český Brod) and central relics (near Tábor), but attains only $\sim 380 \mathrm{~m}$ in the southern relic (near České Budějovice). The most intense subsidence in the Blanice Graben occurred at c. 280-270 Ma.

The tectonic history of the Blanice Graben was also reflected in several episodes of hydrothermal activity: $\mathrm{Au}-\mathrm{Ag}$ (oldest, c. $300 \mathrm{Ma}$ ), $\mathrm{Ag}-\mathrm{Pb}-\mathrm{Zn}$ (most widespread) and U (youngest, c. $260 \mathrm{Ma}$, subeconomic). The geology, mineralogy and tectonic evolution of the $\mathrm{Au}-\mathrm{Ag}$ deposits were summarized by Zachariáš et al. $(2004,2009)$ and Zachariáš and Hübst (2012). The Ag-Pb-Zn, mostly vein-type deposits are characterized by quartz-carbonate gangue, by abundance of galena accompanied by sphalerite and Ag-phases (miargyrite, pyrargyrite, argentite and native silver) and by the scarcity of Fe-sulfides (pyrite, arsenopyrite and pyrrhotite). The most important mining districts from the north to the south are Stříbrná Skalice, Ratibořské Hory-Stará Vožice, and Rudolfov. Similar $\mathrm{Pb}-\mathrm{Zn}$-bearing mineralization, however without known Ag-phases, was also identified in the studied Ševětín Pluton (see below). 
a)

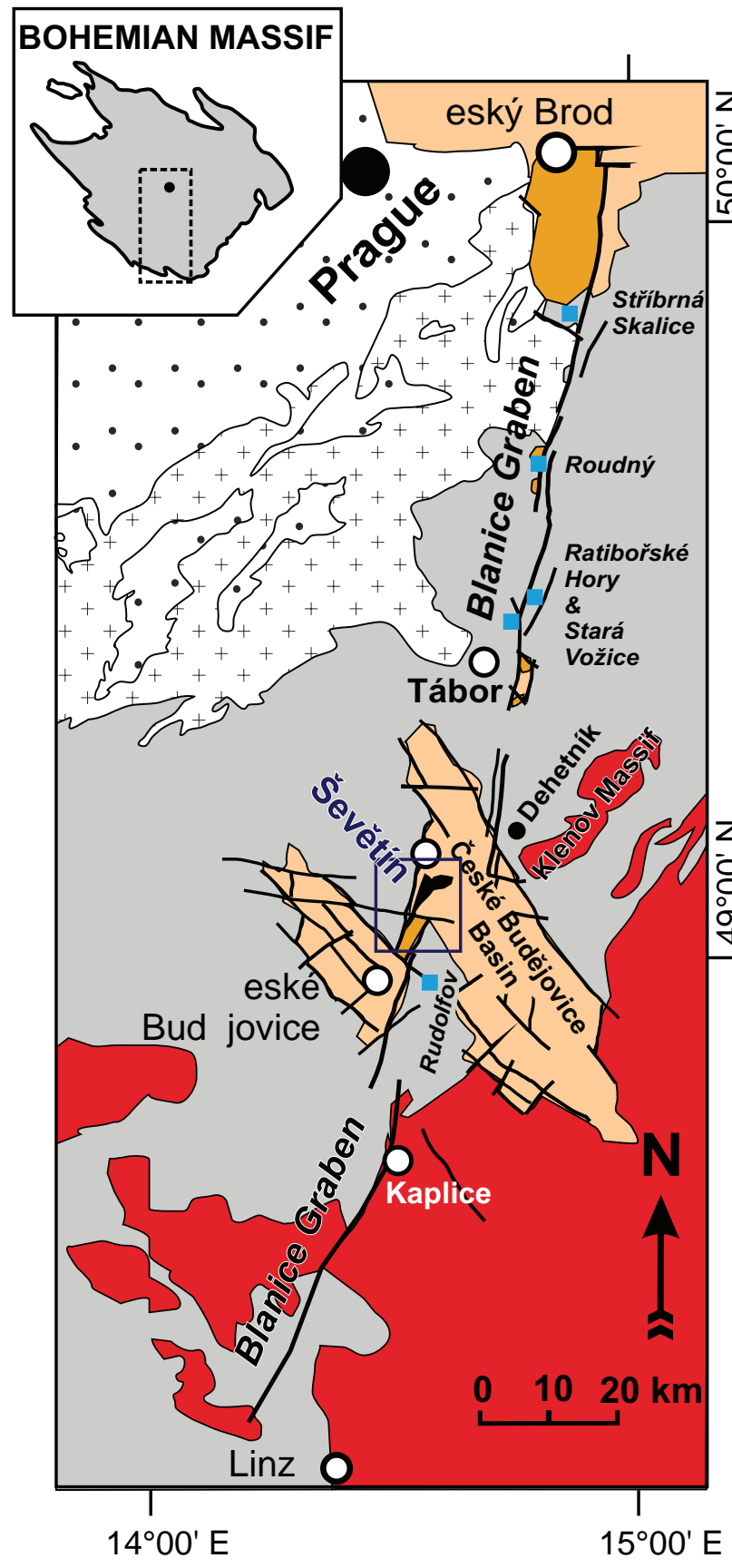

b)

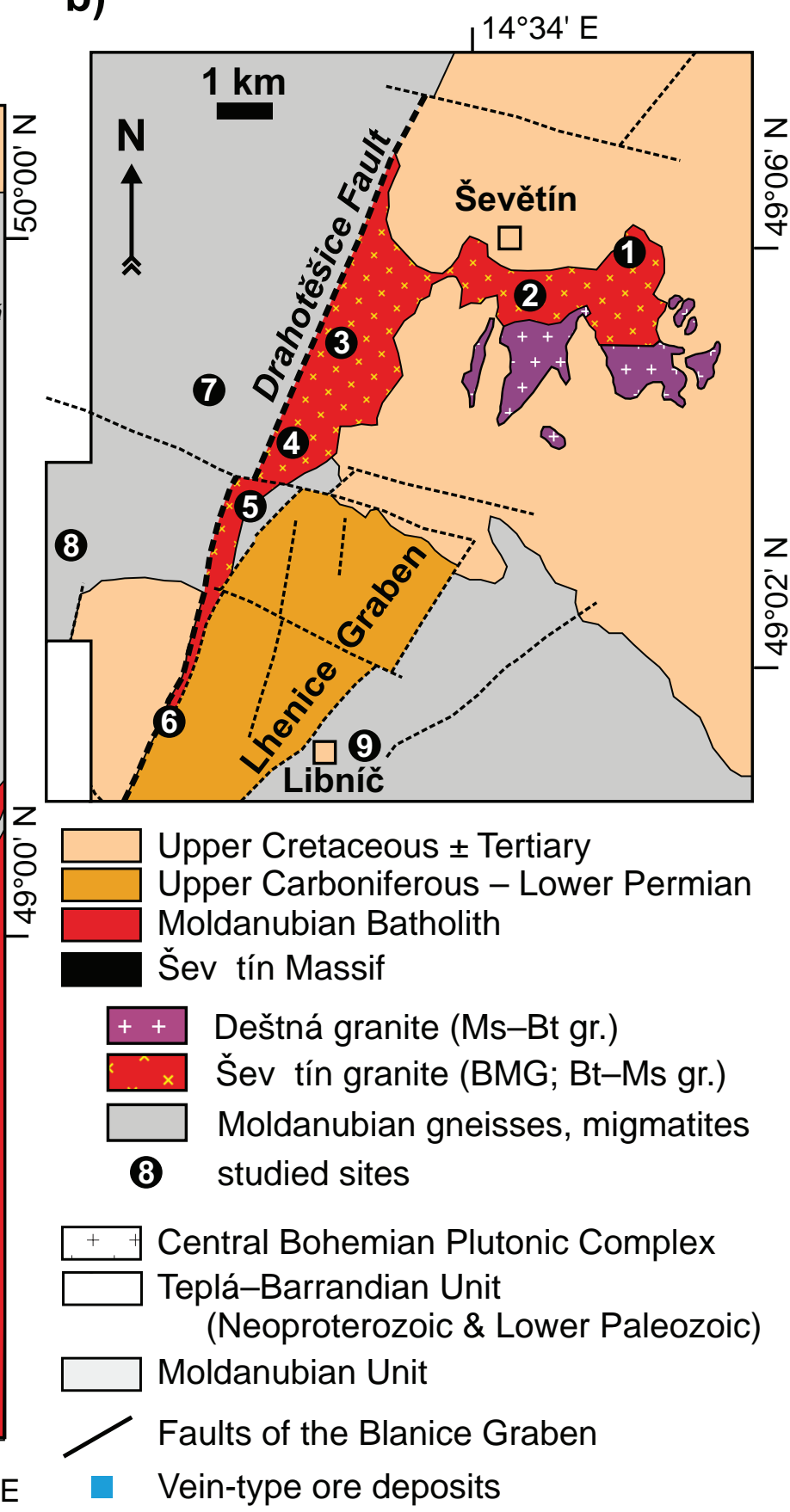

Fig. 1 Simplified geological map of the Blanice Graben (a) and of the Ševětín Pluton (b).

\section{3. Ševětín Pluton}

The Ševětín Pluton (SP) forms a small composite body that intruded the southern part of the Moldanubian Zone c. $15 \mathrm{~km}$ NNE of České Budějovice (Fig. 1a). To the N and NE, it is overlain by the Upper Cretaceous and Tertiary sedimentary rocks of the České Budějovice Basin. The SP shows a triangular shape, apparently stretched along the NNW-SSE trending Drahotěšice Fault (Fig. 1b; a western-peripheral fault of the Blanice Graben system). It is not clear whether this contact is tectonic or intrusive. To the south, the SP narrows down to $<300-500 \mathrm{~m}$ and is partly overlain in its southern parts by Permian sediments of the Lhenice Graben.

Based on gravimetric survey (Čuta et al. 1975; Kadlec et al. 1978; Šalanský 1981) the SP extends to the N, NE 


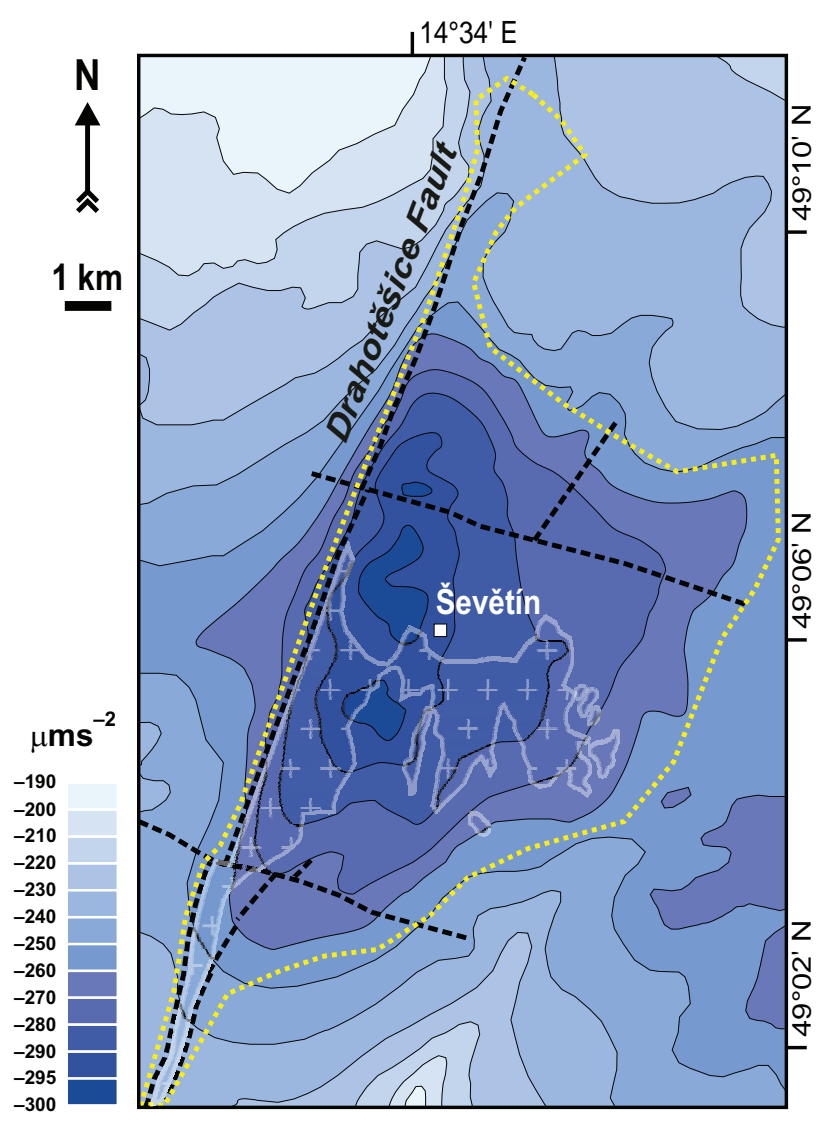

Fig. 2 Bouguer anomaly map of the Ševětín area (after Čuta et al. 1975 and Šalanský 1981). The negative $\Delta \mathrm{g}$ anomaly in the center corresponds to the presence of the Ševětín granite (average density $2620 \mathrm{~kg} / \mathrm{m}^{3}$ ). The dotted line highlights approximate extent of the Ševětín Pluton, based on interpretation of gravity data and sparse drilling (modified after Kadlec et al. 1978).

and $\mathrm{E}$ beneath the sedimentary cover (Fig. 2). The actual size of the Pluton is therefore likely larger than its exposed parts $\left(\right.$ c. $\left.23 \mathrm{~km}^{2}\right)$. Its western contact is steeply dipping and parallel with the Drahotěšice Fault, while the eastern is shallowly dipping. The NNE-SSW trending array of local gravity minima, located about $1.0-1.5$ $\mathrm{km}$ to the $\mathrm{E}$ of the Drahotěšice Fault, may indicate a root zone of the SP.

The SP consists of three principal granite units: (i) two-mica cordierite or cordierite-andalusite-bearing Deštná granite (Klečka et al. 1991; René et al. 1999; Matějka et al. 2003); (ii) biotite-muscovite granite (Suk et al. 1978; Matějka 1991; Janoušek et al. 2002) and (iii) fine-grained biotite granite (Janoušek et al. 2002).

The Deštná granite (DG) represents the oldest intrusive phase and crops out only in the central and southeastern parts of the Pluton, being largely covered by Cretaceous and Tertiary sedimentary rocks. It is medium-grained, locally porphyritic (K-feldspar) and rich in muscovite (muscovite $>$ biotite). Cordierite and andalusite form grains up to $1 \mathrm{~mm}$ in size (Matějka et al., 2003). Its ab- solute age is not known but it is believed to belong to the group of "Eisgarn-type" granites (c. 327-328 Ma; Friedl et al. 1996; Gerdes et al. 2003).

The biotite-muscovite granite (BMG) occupies most of the northern and western parts of the Pluton. It is mediumto fine-grained, locally with biotite clots that resulted from replacement of cordierite by muscovite \pm biotite (Janoušek et al. 2002). Biotite granite (BtG) was recently identified only in the Ševětín quarry and its areal extent is small (c. $200 \times 100 \mathrm{~m}$; Janoušek et al. 2002). Both BMG and $\mathrm{BtG}$ granites were probably coeval and are also collectively referred to as the Ševětín granite. Their absolute age is unknown. The parental magmas of the BMG and $\mathrm{BtG}$ are thought to have represented a mixture of a relatively primitive source (mantle-derived melts or metabasic rocks) and more evolved material geochemically corresponding to mature Moldanubian metasedimentary rocks or to their melts (Janoušek et al. 2002).

The SP was intruded by various dikes: lamprophyre (Ambrož 1935), pyroxene microgranodiorite (Vrána et al. 1993; Košler et al. 2001) and by aplite or leucogranite (this study; Zachariáš and Štrba 2014). The age of the microgranodiorite dike swarm $\left(270 \pm 3 \mathrm{Ma}{ }^{39} \mathrm{Ar}-{ }^{40} \mathrm{Ar}\right.$; Košler et al. 2001) thus represents the lower age limit for the Ševětín granite intrusion.

Brittle-ductile and brittle deformation of the granites is a conspicuous feature of the SP. Both the DG and BMG are strongly deformed, while the BtG is only weakly deformed or even undeformed (Janoušek et al. 2002). The presence of specific deformation features in quartz grains from Ševětín (Vrána 1987), together with some geochemistry indications (Vrána et al. 1993), led these authors to suppose an impact-related origin of the Ševětín structure. This idea was, however, later abandoned (Cordier et al. 1994; Košler et al. 2001).

Various types of hydrothermal mineralization are known from the SP, associated with the individual stages of brittle deformation of the Pluton. These include quartz-feldspar veins, quartz veins and quartz-carbonate veins (e.g. Čtvrtník and Pavlíček 2002; Welser and Zikeš 2009 and references therein). The latter are associated with uneconomic $\mathrm{Pb}-\mathrm{Zn}$ ores, a probable analogue of the $\mathrm{Ag}-\mathrm{Pb}-\mathrm{Zn}$ ores of the Blanice Graben (e.g. Rudolfov and Ratibořské Hory-Stará Vožice ore districts).

\section{Methods}

This paper is based on three methodological approaches: (i) orientation and kinematic analysis of mesoscopic structures on outcrop scale; (ii) paleostress analysis of fault-slip data and (iii) AMS study of preferred mineral orientation, focused on the identification of relic magmatic fabric and of its solid-state modification. 
The study area is relatively flat and outcrops for application of the above methods are scarce. We identified only six suitable localities within, and three outside the Pluton, referred to as SEV1 to SEV9 sites/samples. The most important and also the largest and best exposed site was an active quarry (with dimensions of c. $600 \times 350 \times 50 \mathrm{~m}$ ) in the northern part of the Pluton (SEV2), close to the southeastern margin of the Ševětín village. The number of measured data (mostly joints) at the other sites usually varied from 20 to 45 and was thus significantly less than in the Ševětín quarry (over 300). Therefore, some joint systems discernible in the Ševětín quarry may have been missed elsewhere.

Orientation analysis of structural data was performed in the Stereo32 software. All stereoplots represent lower hemisphere equal area projections, except stated otherwise. Paleostress analysis of fault-slip data was done using the numerical Gauss method (Žalohar and Vrabec 2007); the data were processed by the T-Tecto software (version 3.0; author J. Žalohar; http://www2.arnes. si/ jzaloh/t-tecto_homepage.htm).

A total of 16 oriented cores were sampled using a hand-held drill at 7 stations throughout the Pluton. After cutting, these samples yielded 78 standard specimens with a volume of $10 \mathrm{~cm}^{3}$. The AMS was measured at low field $\left(450 \mathrm{Am}^{-1}\right)$ with a MFK1-A Kappabridge instrument in the Laboratory of Rock Magnetism, Institute of Geology and Paleontology, Charles University in Prague. Statistical treatment and analysis of the AMS data were carried out using the ANISOFT 4.2 program package (http://www.agico.com). All the measured data and parameters are presented in the Electronic Supplement to this article.

The AMS data are represented by the $k_{m}, P$, and $T$ parameters defined as follows: (1) $k_{m}=\left(k_{1}+k_{2}+k_{3}\right) / 3$; (2) $P=k_{1} / k_{3}$ and (3) $T=2 \ln \left(k_{2} / k_{3}\right) / \ln \left(k_{1} / k_{3}\right)-1$; where $k_{1}$ $\geq k_{2} \geq k_{3}$ are the principal susceptibilities. Parameter $k_{m}$ represents the mean bulk magnetic susceptibility, which reflects the proportion and type of magnetic minerals in the analyzed rock. Parameter $P$ (Nagata 1961), the degree of AMS, reflects the eccentricity of the AMS ellipsoid and may thus be related to the intensity of preferred orientation of the magnetic minerals. Parameter $T$ (Jelínek 1981) characterizes the symmetry of the AMS ellipsoid; it varies from -1 (perfectly prolate ellipsoid) through 0 (triaxial ellipsoid) to +1 (perfectly oblate ellipsoid). In magnetic fabric studies, the maximum principal susceptibility $\left(k_{1}\right)$ is referred to as the magnetic lineation and the minimum principal susceptibility $\left(k_{3}\right)$ defines a pole to the magnetic foliation; their orientations are presented in stereograms in the geographic (in situ) coordinate system. GPS coordinates of drill-cores used in the AMS study as well as of other studied sites are given in the Electronic Supplement. All the data were collected in 2012 and 2013.

\section{Results}

\subsection{Orientation analysis of brittle structures in the Ševětín quarry}

\subsubsection{Joints}

Joints of several generations represent the most ubiquitous mesoscopic phenomena in the Ševětín Pluton. In total, we distinguished six types of joints (referred to as $\mathrm{P}_{1}$ through $\mathrm{P}_{6}$ ) in the quarry with respect to their orientation (Fig. 3).
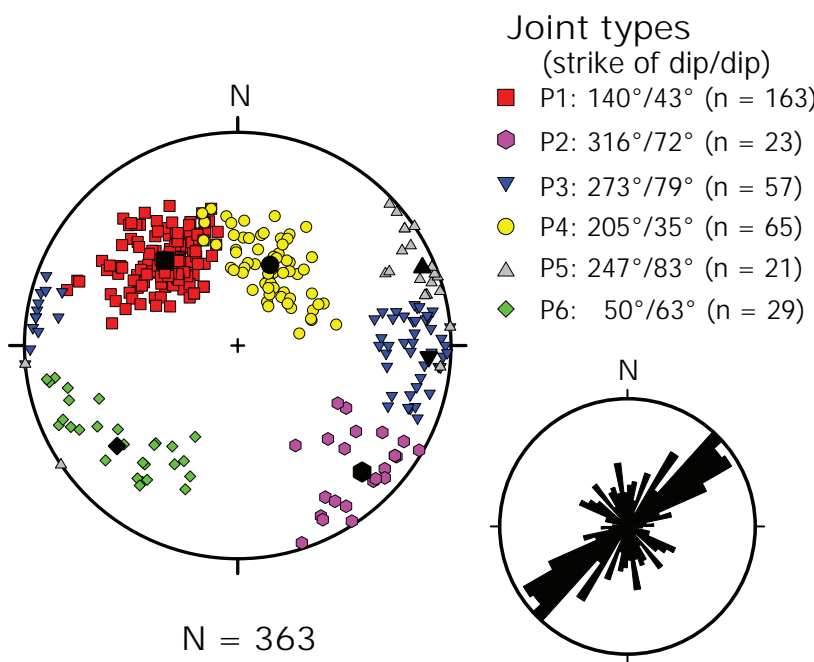

Fig. 3 Summary plot of poles of joints from the active Ševětín quarry and rose diagram of joint strikes. The maxima of the individual joint types given in the legend were converted from the respective eigenvectors.

$P_{1}$ joints represent the most prominent structures in the quarry (Fig. 4a). They strike NE-SW and dip moderately to SE. They are regularly spaced (about 5-20 cm) and represent typical extension joints as indicated by the frequent presence of plumose hackles and rib marks (Fig. 4b). The longitudinal axis of rib marks is roughly identical with the dip line and their shape implies stepward propagation of $\mathrm{P}_{1}$ joints upward along the dip line. The visibility of ribs and hackles is highlighted by greenish coatings of epidote-chlorite and by even younger scarce coatings of calcite.

$P_{2}$ joints are much less frequent than $\mathrm{P}_{1}$. Strictly geometrically, they resemble a conjugate system to $\mathrm{P}_{1}$ joints. However, we found no unambiguous evidence for the presence of a conjugate $\mathrm{P}_{1}-\mathrm{P}_{2}$ system.

$P_{3}$ joints are steep, $\mathrm{N}-\mathrm{S}$ trending and locally filled in by veins of greyish quartz. Some of $\mathrm{P}_{3}$ joints contain hackles and rib marks; however, they are less visible than those at the $\mathrm{P}_{1}$ joints. Locally, the joints may display systematic down-slip of northern segments (Fig. 4c). 

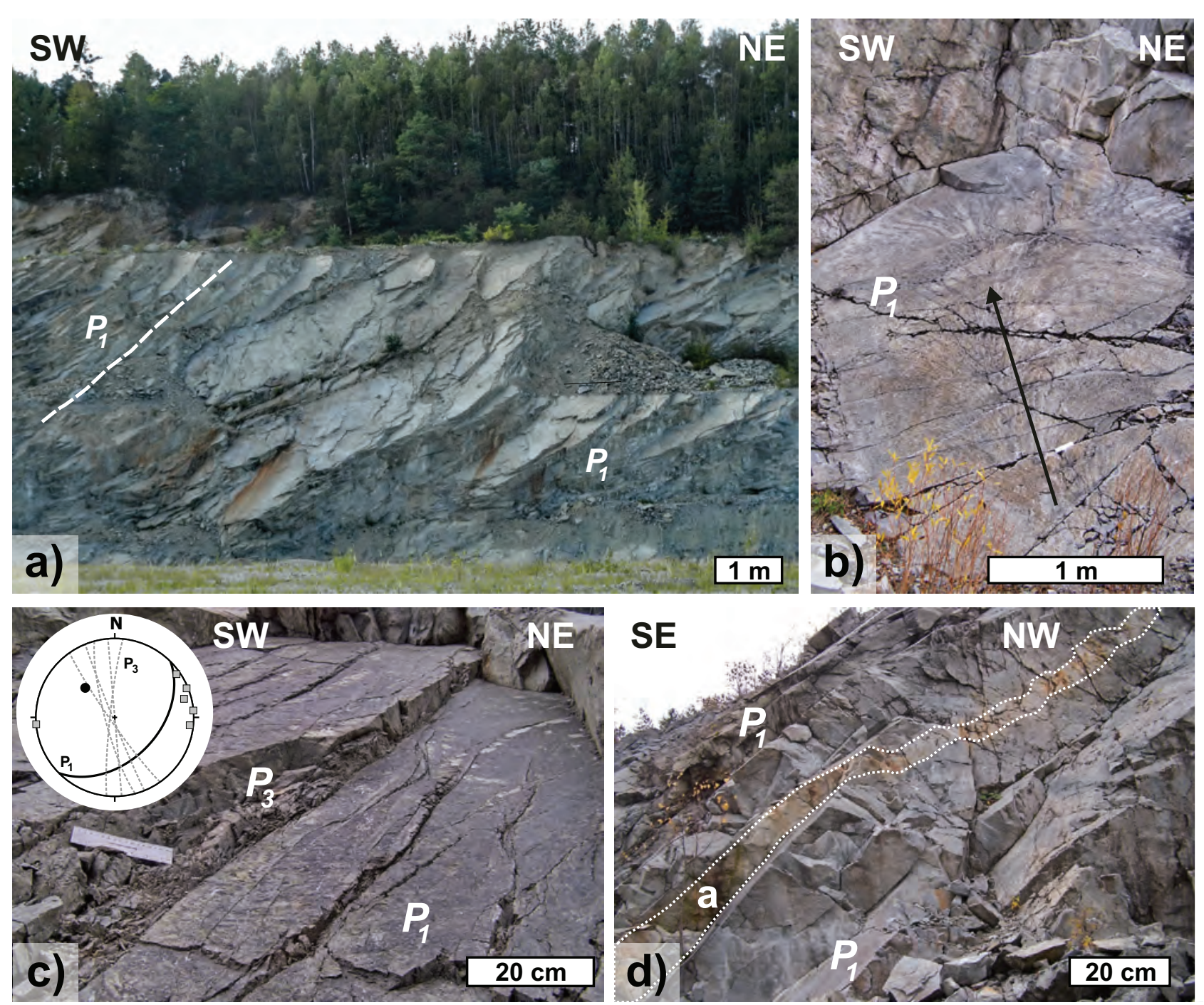

Fig. 4 Photos of $\mathrm{P}_{1}$ joints at the new Ševětín quarry: $\mathbf{a}$ - Moderately inclined $\mathrm{P}_{1}$ joins in the southwestern wall of the quarry. $\mathbf{b}-\mathrm{Detail}$ of plumose hackles and rib marks on the surface of a $\mathrm{P}_{1}$ joint. The arrow indicates the axis of the plume and upward direction of the fracture opening. $\mathbf{c}-\mathrm{P}_{1}$ joint crosscut by steep $\mathrm{P}_{3}$ joints, accompanied by systematic down-throw of the northeastern segments. $\mathbf{d}-$ Dike of aplite intruding the BMG between two $\mathrm{P}_{1}$ joints.

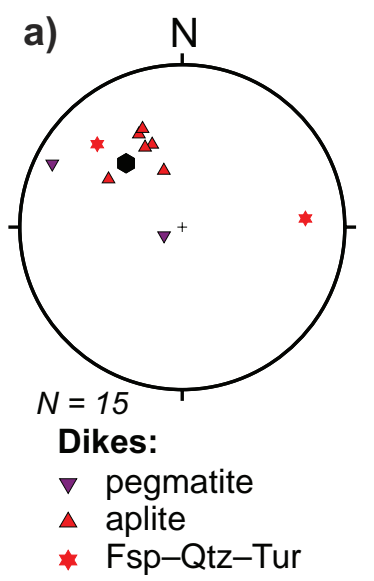

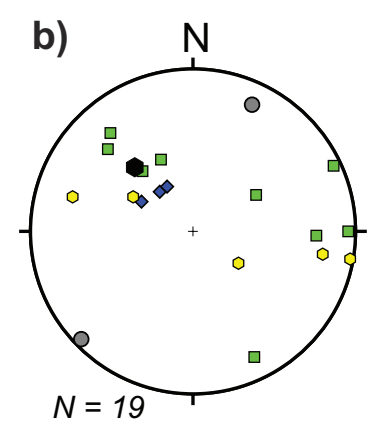

Quartz veins:

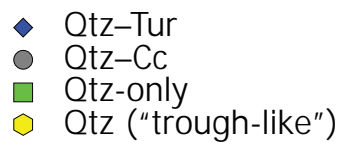

Q Qtz ("trough-like")

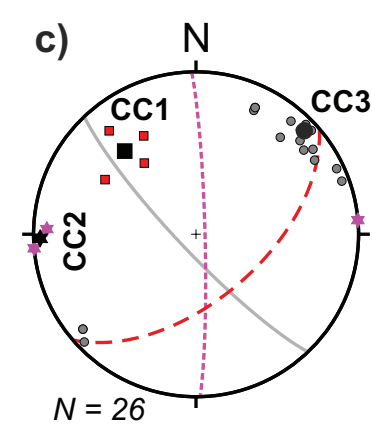

Calcite veins:

CC1 $(139 / 57)$

CC2 $(89 / 85)$

CC3 $(227 / 81)$

- maximum of $\mathrm{P}_{1}$ joints

Therefore, they represent most probably mixed Mode I-II fractures.

$\mathrm{P}_{4}$ joints strike mostly NWSE and dip moderately to the SW. They frequently show evidence for shear movements and usually do not crosscut $\mathrm{P}_{1}$ joints. Some are rimmed by feldspathic masses (up to 1.5 $\mathrm{cm}$ thick), while the others host veins of greyish quartz.

Fig. 5 Summary diagrams for intrusive dikes (a), quartz veins (b) and calcite veins (c) observed in the BMG granite in the Ševětín quarry. 
$P_{5}$ and $P_{6}$ joints are oriented WNW-ESE and dip steeply to the NE to ENE $\left(\mathrm{P}_{5}\right)$ or to $\mathrm{SE}\left(\mathrm{P}_{6}\right)$. Some $\mathrm{P}_{5}$ joints were filled in by late calcite veins (CC3). Both calcite veins and $\mathrm{P}_{5}$ joints represent extension fractures (Mode I).

\subsubsection{Dikes}

We identified several aplite and pegmatitic dikes in the quarry. The largest is a pinkish aplite $\sim 20 \mathrm{~cm}$ thick, at least $70-60 \mathrm{~m}$ long along its strike, and $c .10 \mathrm{~m}$ along the dip. It is parallel or subparallel to $\mathrm{P}_{1}$ joints (Fig. 4d). Other observed aplite dikes are much smaller, mostly less than $5 \mathrm{~cm}$ thick, and of a more variable orientation. Most of them, however, are still subparallel with $\mathrm{P}_{1}$ joints (Fig. 5a).

In addition to aplite, several dikes of leucocratic granite (10 to $50 \mathrm{~cm}$ thick) can be found in the southwestern wall of the quarry, but these were not accessible for direct structural measurements. It can be seen in Fig. 6 that these dikes are first parallel to $\mathrm{P}_{1}$ joints, but later steepen and finally one of them approaches almost vertical orientation at the bottom of the quarry wall. Another felsic but much thicker zone (dike?) is located above these dikes and is also parallel to $P_{1}$ joints.

\subsubsection{Hydrothermal veins}

Several types/generations of hydrothermal veins and of transitional late-magmatic to early hydrothermal products can be identified in the Ševětín quarry. The latter are represented by fractures/veins with feldspathic rims, which may contain quartz, hornblende and/or tourmaline in the core. They are usually less than $2 \mathrm{~cm}$ thick and mostly parallel to $\mathrm{P}_{1}$ joints.

Probably three generations of hydrothermal quartz veins exist in the quarry (Fig. 5b): (i) The undoubtedly oldest, less than $5 \mathrm{~mm}$ thick quartz veinlets with tourmaline, slightly oblique to $\mathrm{P}_{1}$ joints and locally crosscutting them; (ii) Up to several $\mathrm{cm}$ thick veins of greyish quartz (with finely disseminated chlorite and/or pyrite), more or less subparallel to $\mathrm{P}_{4}$ joints and (iii) Older growth zones in the veins of late calcite (CC3).

With respect to their orientation, three clusters of calcite veins and veinlets were identified (Fig. 5c) and referred to as $\mathrm{CC} 1, \mathrm{CC} 2, \mathrm{CC} 3$. Veins of the late calcite (CC3) are the most frequent. They are extensional in nature, as indicated by bilaterally symmetrical growth zones and less frequently by crustiform or breccia textures. We found them associated with $\mathrm{P}_{5}$ joints, but they may also accompany the main fault (being parallel with it). Čtvrtník and Pavlíček (2002) described about $20 \mathrm{~cm}$ thick calcite vein (CC3?) with abundant sphalerite and/or galena spatially associated with the main fault. However, we found only one calcite vein with sparse sphalerite grains. The other two groups $(\mathrm{CC} 2, \mathrm{CC} 1)$ may represent two separate and older but volumetrically minor calcite generations. Alternatively, they may have been coeval with the $\mathrm{CC} 3$ group as the fluids just reached structures of different orientation.

\subsubsection{Faults and fault-slip data}

Two major more or less parallel faults (striking NE-SW and inclined 70 to $85^{\circ}$ to the SE) crop out in the Ševertín quarry (for details, see Zachariáš and Štrba 2014). They are oblique to the Drahotěšice Fault and are associated with numerous second-order small-scale faults. The fault plane of the western fault is flanked by c. $0.5 \mathrm{~m}$ wide zone of friable gouge of dark appearance. Rocks in an about 50-80 m wide zone between these two faults are highly fractured. Although both faults probably accumulated most of the brittle deformation, the fault planes themselves are almost free of identifiable striation. Striations

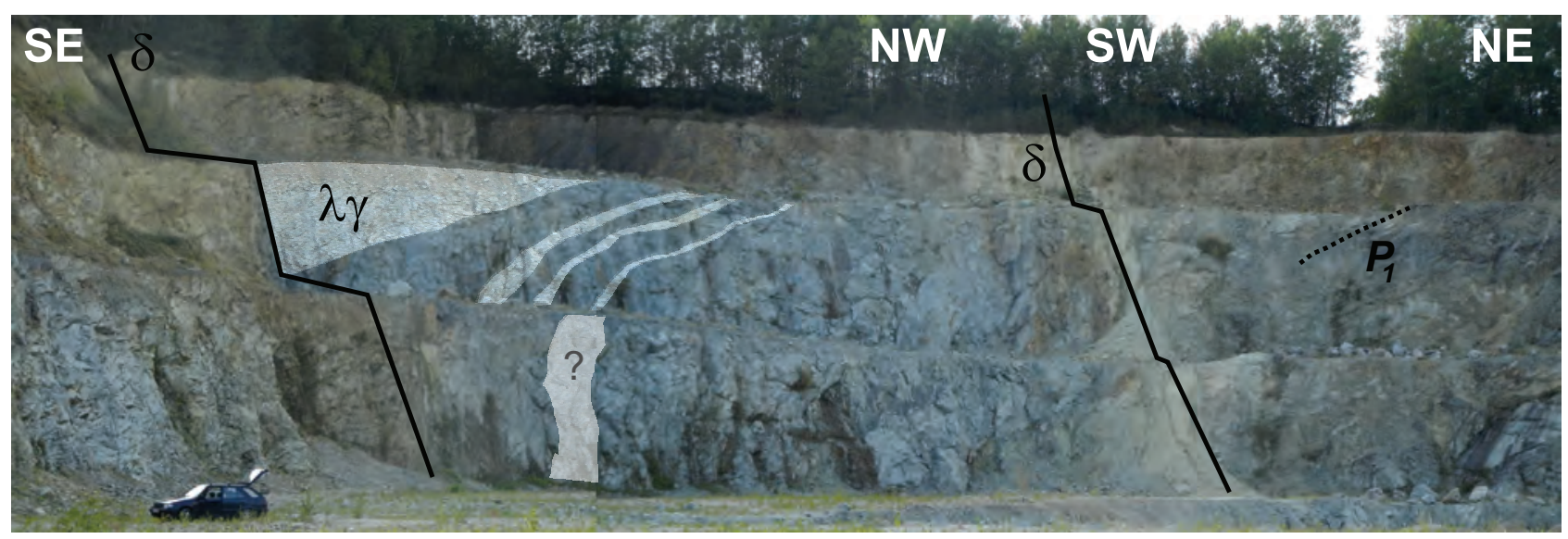

Fig. 6 Parallel dikes of leucogranite (highlighted by shading) in the southern wall of the active Ševětín quarry. Note they are initially parallel with $\mathrm{P}_{1}$ joints, but later become much steeper. 

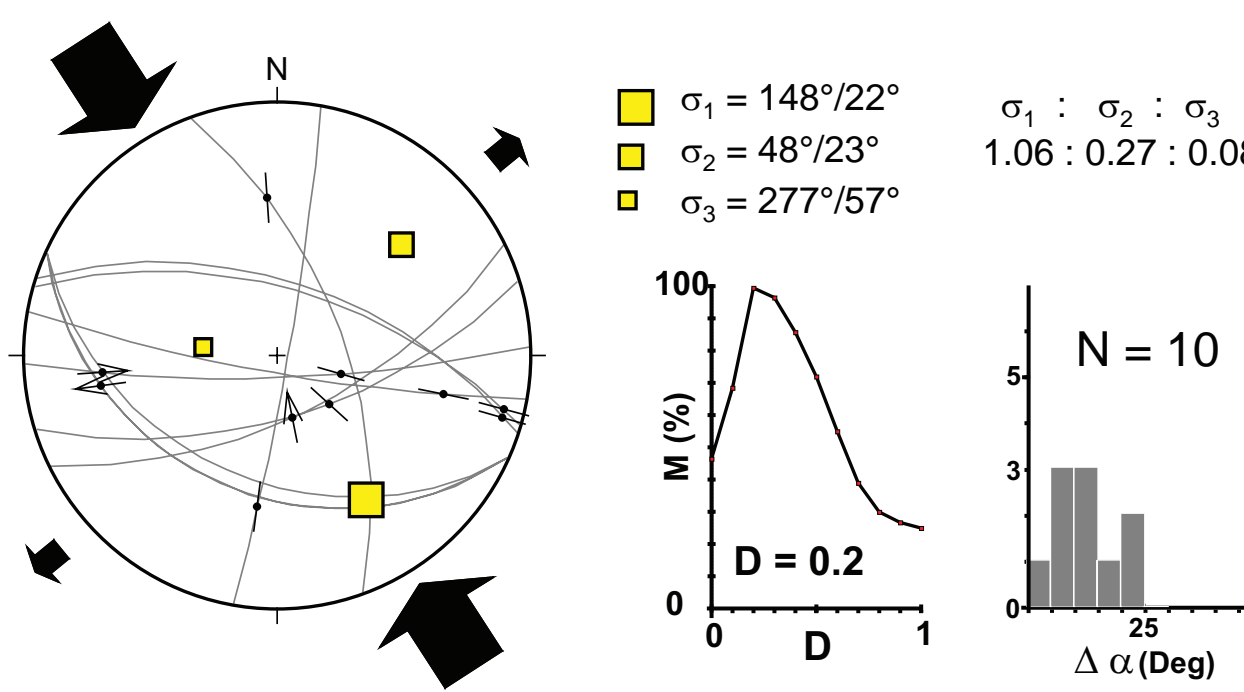

$1.06: 0.27: 0.08$

$\sigma_{3}=277^{\circ} / 57^{\circ}$
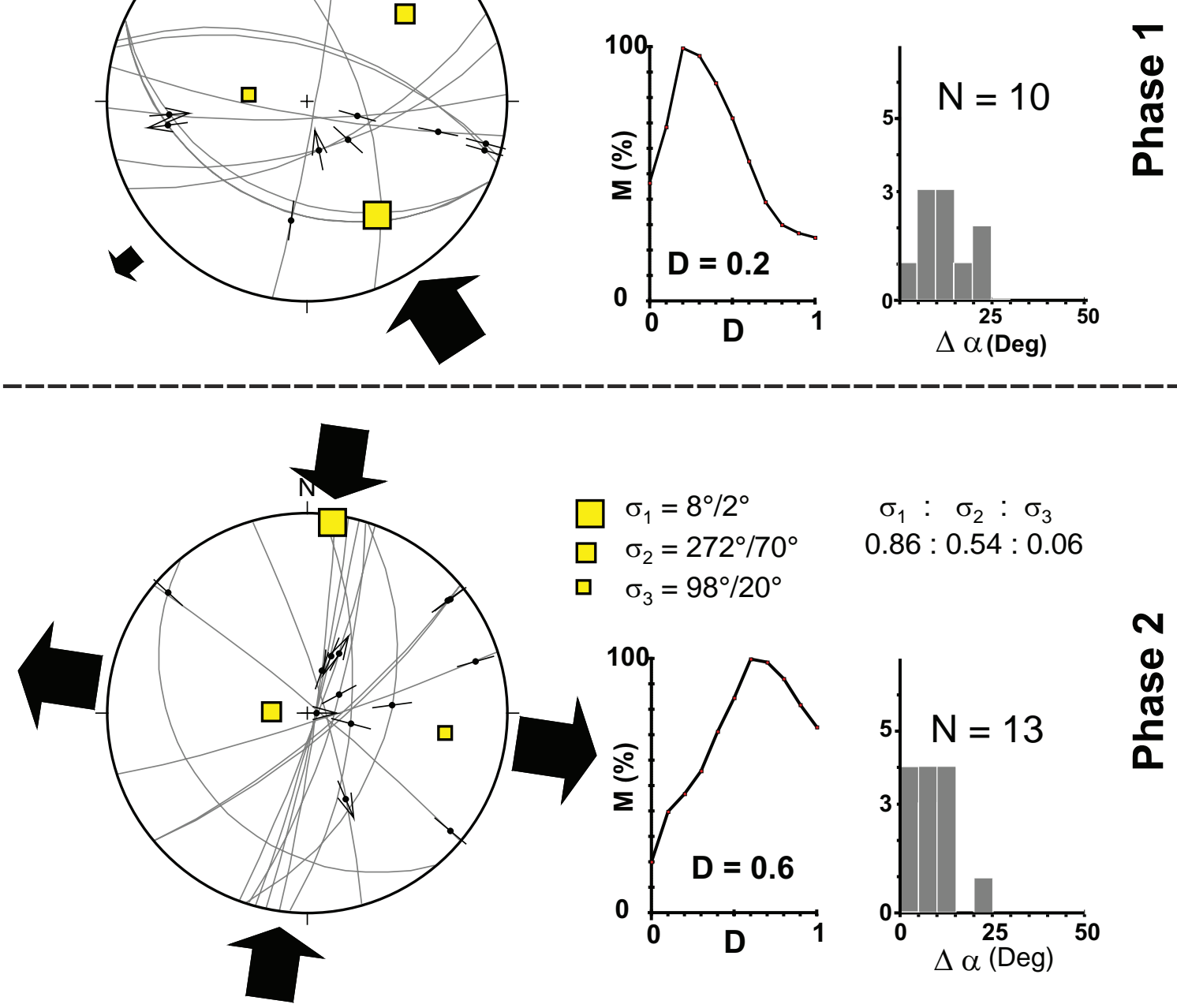

$\sigma_{1}: \sigma_{2}: \sigma_{3}$

$0.86: 0.54: 0.06$

$\sigma_{3}=98^{\circ} / 20^{\circ}$

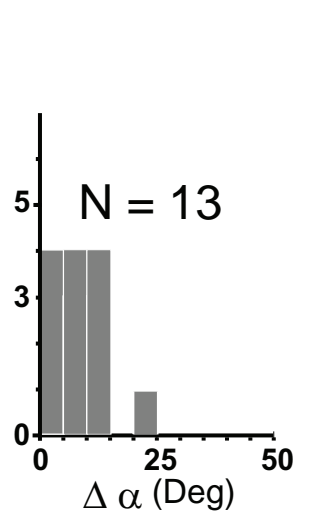

N

0
$\frac{0}{0}$
$\frac{1}{\alpha}$
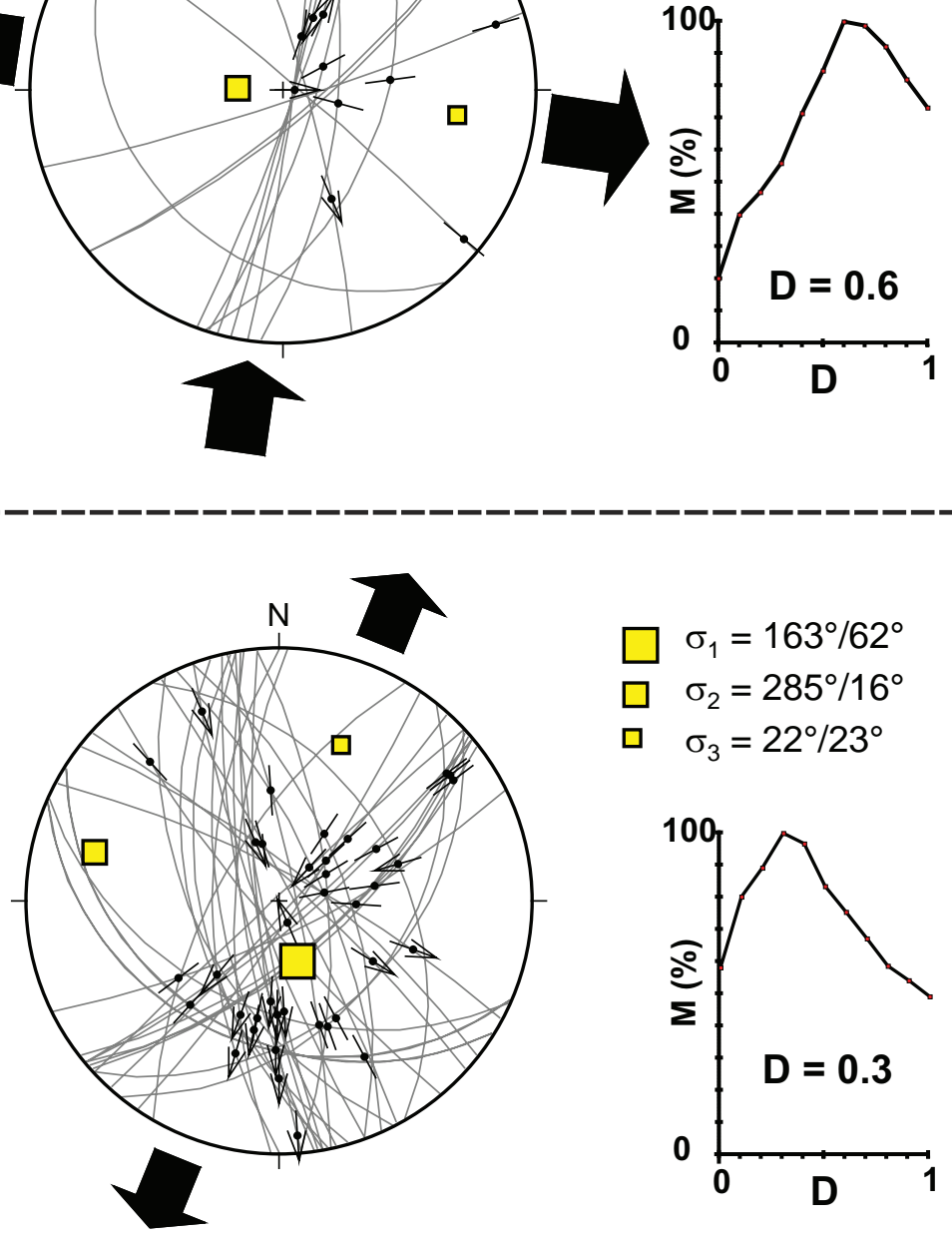

$\square \sigma_{1}=163^{\circ} / 62^{\circ}$
$\square \quad \sigma_{2}=285^{\circ} / 16^{\circ}$
$\square \quad \sigma_{3}=22^{\circ} / 23^{\circ}$

$\sigma_{1}: \sigma_{2}: \sigma_{3}$

$1.01: 0.35: 0.07$
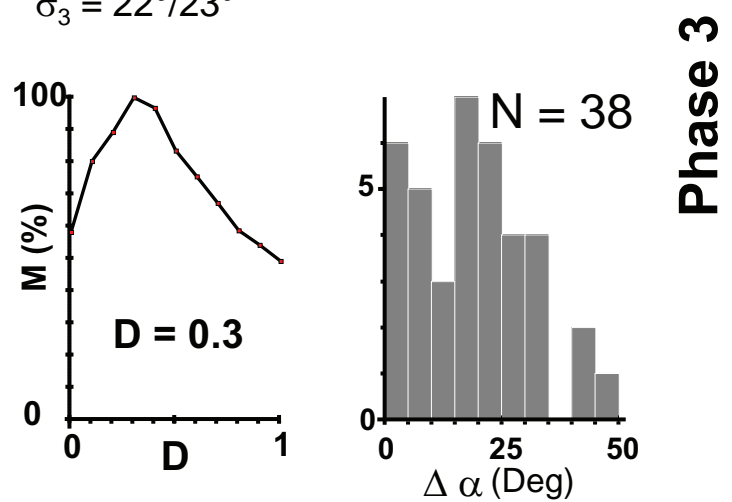
are, however, rather frequent within the highly fractured zone. We identified a total of 65 fault planes with slickenlines in the Ševětín quarry that were included in the paleostress analysis. Fault-slip data from other sites were sparse (less than three per locality) and thus excluded.

\subsubsection{Paleostress analysis of fault-slip data}

Our calculations started with a larger maximum misfit value $\left(50-60^{\circ}\right)$ between the theoretical and real slip vectors and were repeated until lower misfit values $\left(15-20^{\circ}\right)$ and numerically stable solutions were obtained. The analysis resulted in the separation of fault-slip data into three populations representing separate tectonic phases (Fig. 7). They differ in the orientation of the paleostress axes and in the stress ratio [represented by the $\mathrm{D}$ parameter, where $\left.\mathrm{D}=\left(\sigma_{2}-\sigma_{3}\right) /\left(\sigma_{1}-\sigma_{3}\right)\right]$.

Phase 1 represented an oblique compression regime, with the maximum principal stress in the NW-SE direction. The minimum principal stress $\left(\sigma_{3}\right)$ was moderately inclined to the $\mathrm{W}$.

Phase 2 reflected a strike-slip regime, as indicated by subvertical orientation of the intermediate stress axis $\left(\sigma_{2}\right)$. The maximum principal stress $\left(\sigma_{1}\right)$ was oriented $\mathrm{N}-\mathrm{S}$ and the least principal stress $\left(\sigma_{3}\right) \mathrm{E}-\mathrm{W}$.

Phase 3 corresponded to an extensional regime with maximum subhorizontal $\sigma_{3}$ in the NNE-SSW direction.

\subsection{Orientation analysis of brittle structures on a regional scale}

Three to four dominant joint systems are identified on a regional scale: the $\mathrm{P}_{1}$ system is best recognizable in the northern part of the SP (Fig. 8; sites 1-3), but is still identifiable across the whole Pluton. At a single locality (site 4), the $P_{1}$ system grades into steep joints, similar in orientation to $\mathrm{P}_{3}$ joints at the Ševětín quarry (site 2). Most localities, and notably the abandoned quarry south of the village of Vitín (site 3; the second largest outcrop after the Ševětín quarry), lack $\mathrm{P}_{4}$ joints.

\subsection{Ductile structures in the surrounding Moldanubian unit}

Localities outside the Ševětín Pluton are represented by sillimanite-biotite paragneisses (site 7), migmatites

Fig. 7 Separation of fault-slip data, based on paleostress inversion analysis using the Gauss method (Žalohar and Vrabec 2007), into three stress phases. All stereoplots represent lower hemisphere equal angle projections. Solid arrows indicate orientations of maximum horizontal compression and/or extension. The other diagrams show the confidence of the parameter $D$ estimate and histograms of deviation between the calculated and measured slip vectors. (site 8) and migmatitic biotite gneisses (site 9). They all show subhorizontal metamorphic foliation $\left(\mathrm{S}_{1}\right.$; Figs 8 and $9 a)$. Stretching lineation $\left(\mathrm{L}_{1}\right)$ is, however, visible only in the paragneiss (site 7), where it is subhorizontal and trends NW-SE (Fig. 9b). At the same locality we also identified open folds with moderately inclined axial planes and with well-developed second-order chevronlike folds in the hinge zones (Fig. 9b). All the folds exhibit the same axis orientation, identical with the strike and dip of the stretching lineation.

\subsection{Magnetic fabric parameters and orientation of the Ševětín Pluton}

\subsubsection{Bulk susceptibility}

The bulk magnetic susceptibility of the measured specimens is of the order of $10^{-5}$ (Fig. 10a; SI units are used throughout this paper), characteristic of paramagnetic granites (e.g., Hrouda and Kahan 1991; Bouchez 1997). A slight increase in the bulk susceptibility can be seen from the sample SEV2b $\left(32 \times 10^{-6}\right.$ to $\left.39 \times 10^{-6}\right)$ through the SEV2c, SEV3, SEV4 $\left(60 \times 10^{-6}\right.$ to $\left.73 \times 10^{-6}\right)$ to the SEV2a, SEV6 and SEV1 $\left(74 \times 10^{-6}\right.$ to $\left.104 \times 10^{-6}\right)$.

\subsection{2. $\mathrm{P}$ and $\mathrm{T}$ parameters}

The Ševětín granite is characterized by a low degree of anisotropy not exceeding 1.2 (corresponding to $12 \%$ magnetic anisotropy) for most of the analyzed specimens (Fig. 10b).

Sample SEV1 $(P=1.013-1.054)$ is the least anisotropic, SEV2b $(P=1.040-1.058)$, SEV2c $(P=1.033-$ 1.069 ; one outlier with $P=1.263)$ and SEV3 $(P=$ $1.024-1.084)$ are slightly more so. The degree of anisotropy of samples SEV2a and SEV4 is more widely scattered from 1.044 to 1.085 (Fig. 10b). The highest degree of anisotropy was measured in the SEV6 specimen $(P=1.072-1.119)$.

In contrast to the slight differences in the $P$ parameter, the granites exhibit a mutually comparable range of shape parameter from highly prolate ( $T$ as low as -0.826 ) to highly oblate ( $T=0.879$ at most), as well as a distinct trend of concomitantly increasing oblateness and degree of anisotropy (Fig. 10b).

\subsubsection{Orientations}

In terms of orientation, all the granite samples except SEV3 and SEV6 exhibit N-S to NE-SW trending, steep to moderately dipping magnetic foliation, indicated by clusters of the $k_{3}$ axes in the stereonet (Fig. 11a). In 


\section{Ševětín granite}

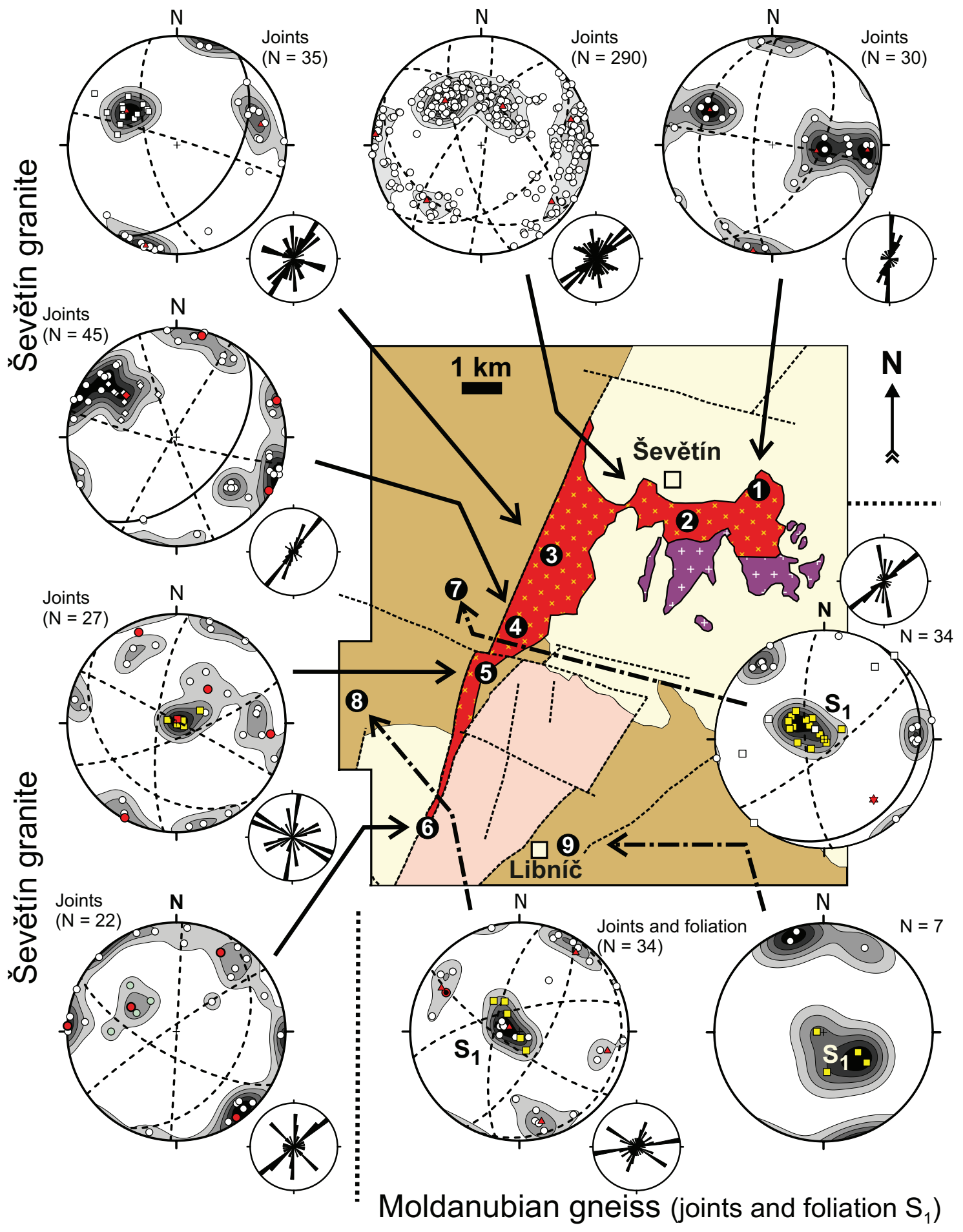

$\square$ Tertiary sediments ${ }^{*} \times$ Crd-Bt granodiorite $\square$ Moldanubian gneisses, migmatites and orthogneisses

Permian sediments
+++ Ms-Bt granite
Fig. 8 Orientation of joints and of metamorphic foliation $\left(\mathrm{S}_{1}\right)$ in the Ševětín Pluton and its neighborhood. 

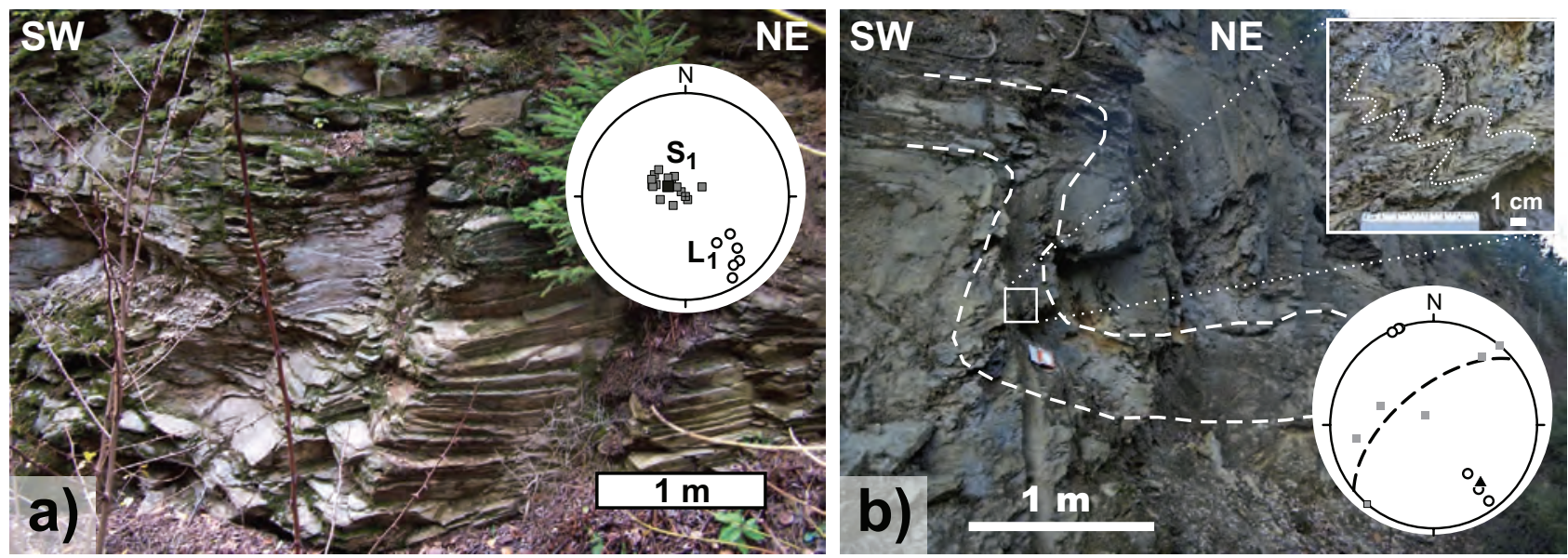

Fig. 9a - Subhorizontal metamorphic foliation $\left(\mathrm{S}_{1}\right)$ of biotite paragneiss in the railway cut near Chotýčany (Stop 5). The stereogram shows the orientation of the poles of metamorphic foliation ( $\mathrm{S}_{1}$; full squares) and of metamorphic stretching lineation ( $\mathrm{L}_{1}$; open circles). $\mathbf{b}-\mathrm{Local}$ development of a small-scale flexure/fold in paragneiss from the same outcrop as the previous photo. The inserted photograph documents second-order chevron-like folds in the hinge zone of the main fold. The stereogram shows the orientation of fold limbs (full squares), of measured fold axes of chevron-like folds (open circles) and of the constructed $\pi$-pole (full triangle) and circle (dashed). Note the identical trend and plunge of metamorphic stretching lineation and of fold axes.

sample SEV3, the magnetic foliation is also steep; however, it trends NW-SE. Notably, individual $k_{3}$ axes in this sample are broadly scattered along a girdle with a pole located at the maximum magnetic lineation (maximum of the $k_{1}$ axes). Magnetic foliation in the sample SEV6 trends $\mathrm{E}-\mathrm{W}$.

Magnetic lineations ( $k_{1}$ axes) are usually well defined and of subhorizontal plunge. They trend $\mathrm{N}-\mathrm{S}$ to NE-SW, except samples SEV6 (E-W) and SEV3 (NW-SE) and form clusters in the stereonet. The only exception is sample SEV1, where the individual $k_{1}$ axes are scattered along a girdle with a pole at the maximum of the $k_{3}$ axes.

\section{Discussion}

\subsection{Relative age relationships between joints, dikes and veins}

The $\mathrm{P}_{1}$ joints represent the oldest population of joints because: (i) late magmatic dikes of aplite and leucogranite show similar orientation as $\mathrm{P}_{1}$ joints (Fig. 4a); (ii) neither the aplite dikes are crosscut by $\mathrm{P}_{1}$ joints, nor are the $\mathrm{P}_{1}$ joints cut by the dikes (Fig. $4 \mathrm{~d}$ ) and (iii) $\mathrm{P}_{1}$ joints are displaced by other types of joints $\left(\mathrm{P}_{3}, \mathrm{P}_{4}, \mathrm{P}_{5}\right.$; see Fig. $\left.4 \mathrm{c}\right)$.

Displacement relationships indicate that $\mathrm{P}_{4}$ joints are older than $\mathrm{P}_{5}$. Late formation of $\mathrm{P}_{5}$ and $\mathrm{P}_{6}$ joints can be
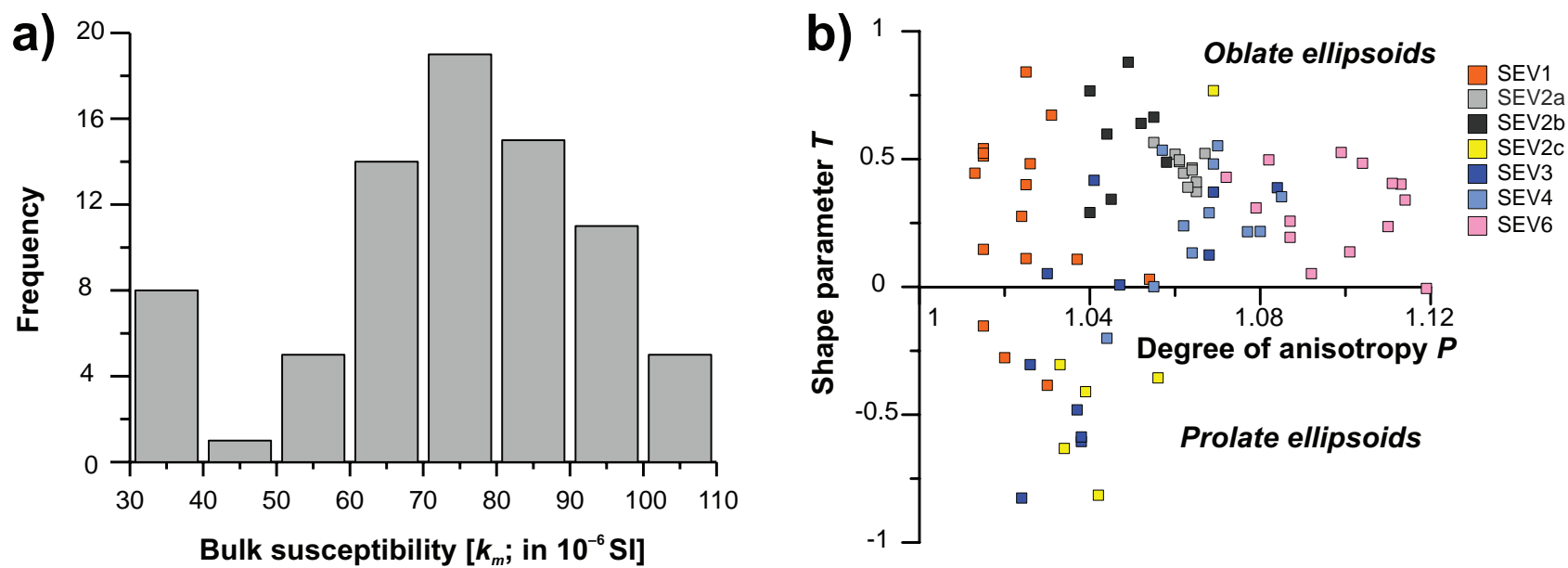

Fig. 10 Magnetic properties for all the studied samples from the Ševětín Pluton: a - Summary histogram of the mean magnetic susceptibility; b - Magnetic anisotropy P-T plot. 


\section{a) AMS fabrics}
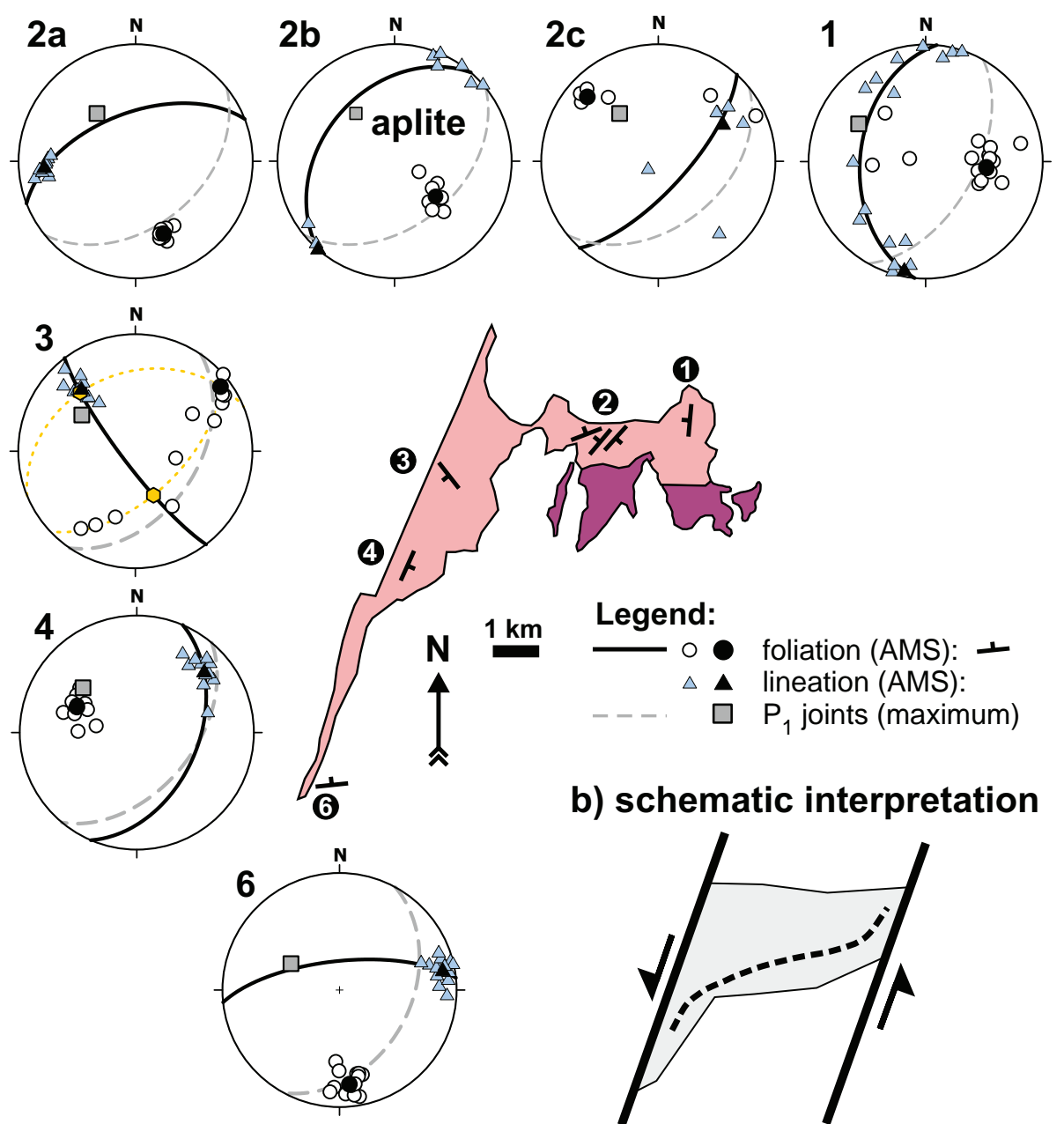

Legend:

- foliation (AMS): -

$\triangle \Delta$ lineation (AMS):

$\square \quad P_{1}$ joints (maximum)

b) schematic interpretation

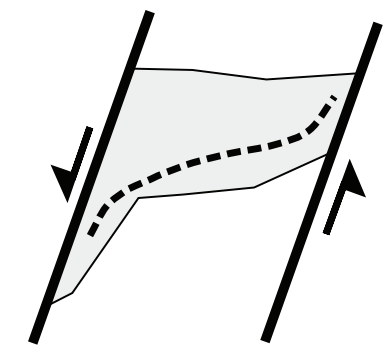

Fig. 11a - Orientation of magnetic foliation (poles represented by the $k_{3}$ axes and by the mean plane) and lineations (represented by $k_{1}$ axes) at the Ševětín Pluton. The orientation of $\mathrm{P}_{1}$ joints (mean pole and plane) is also plotted, for comparison with Fig. 8. The apparent inverse orientation of $k_{1}$ and $k_{3}$ axes at the site 3 (SEV3), compared to other sites, may be due to the presence of cordierite, while the magnetic susceptibility of the other samples is controlled by biotite and muscovite. $\mathbf{b}$ - Schematic summary of magnetic foliation trends across the Ševětín Pluton. The overall sigmoidal shape of this trend points to mostly solid-state deformation of the Ševětín granite during oblique sinistral movements on the main faults of the Blanice Graben. deduced indirectly from spatial association of extension veins of late calcite $(\mathrm{CC} 3)$ with these joints. Relative age of $\mathrm{P}_{2}$ joints remains questionable. Similar orientation of $\mathrm{P}_{2}$ joints and of $\mathrm{CC} 2$ calcite points to post $-\mathrm{P}_{1}$ and pre- $\mathrm{P}_{5}$ nature of $\mathrm{P}_{2}$ joints.

\subsection{Summary of the intrusive and deformational evolution of the Ševětín Pluton}

\subsubsection{Late metamorphic phase}

The metamorphic foliation ( $\mathrm{S}_{1}$; this study) in Moldanubian rocks to the W and SE of the SP can be, on regional scale, correlated with the subhorizontal foliation $\mathrm{S}_{4}$ of Franěk et al. (2011). Its formation was related to the LP-MT stage of deformation of the Moldanubian Unit at c. $340 \mathrm{Ma}$ (Franěk et al. 2011). Further to the $\mathrm{E}$ of the SP, the metamorphic foliation becomes gradually steeper due to diapiric formation of the Pelhrimov granite-dome Complex (Verner et al. 2014) at c. 328-327 Ma. In contrast to the Pelhřimov Com- plex (Klenov Pluton) the relations between the metamorphic fabrics in the Moldanubian rocks, and the magmatic and solid-state deformation fabrics in the SP are more obscure: (i) the BMG lacks mesoscopically visible magmatic fabrics as well as clear $\mathrm{S}_{1}$ overprint; (ii) there is no change in the dip of $\mathrm{S}_{1}$ foliation in the Moldanubian rocks towards the SP; (iii) the magnetic foliation of the SP is much steeper than the metamorphic foliation; (iv) sparse folds in the Moldanubian paragneisses with axial planes trending NW-SE and dipping moderately to SW (Fig. 9b) must have postdated the $\mathrm{S}_{1}$ foliation and indicate NE-SW oriented local shortening.

\subsubsection{Intrusion of the Ševětín Pluton}

The SP is volumetrically dominated by two intrusive units: the Deštná granite (DG) and the biotite-muscovite granite (BMG). Their absolute intrusive ages are not known; however, the DG is petrologically and geochemically similar to the Klenov granite that has been recently dated at $328.4 \pm 0.2$ $\mathrm{Ma}$ and 327.1 $\pm 0.2 \mathrm{Ma}$ (U-Pb monazite; Verner et al. 2014), while the BMG might be similar in age to the Freistadt 
granodiorite (302 \pm 2 Ma; Friedl et al. 1992), or slightly older. An age of c. $305 \mathrm{Ma}$ for BMG would be compatible with the onset of sedimentation in the Blanice Graben, as well as with the oldest dated tectonic and intrusive activity at the Rödl fault zone (Vrána et al. 2005). The two intrusive units also differ in shape: the DG is only slightly elongated in the E-W to ENE-SWS direction, while the BMG is markedly stretched in NNE-SSW direction (Figs 1 and 2), i.e. parallel with the strike of the Blanice Graben. Temporal separation of the BMG and DG intrusions is therefore possible.

The mean magnetic susceptibility of all the studied samples (Fig. 10a) indicates that micas are the main carrier of the susceptibility. This is also reflected in the dominant planar fabric. The BMG almost lacks evidence for ductile deformation; therefore, we consider the planar magnetic fabric to reflect magmatic foliation. The AMS fabric pattern reveals a transition from NNESSW trending foliation at the eastern margin of the SP, through NE-SW trending foliations in the center, back to NNE-SSW trends at the western margin. The overall sigmoidal pattern (Fig. 11b) of magnetic foliation across the SP points either to synkinematic intrusion of the BMG during sinistral strike-slip activity on the Blanice Graben fault system or to subsolidus modification of magmatic foliation (trending $\mathrm{E}-\mathrm{W}$ to $\mathrm{NE}-\mathrm{SW}$ ) during sinistral strike-slip motion. The latter option is supported by moderate gradual increase in the anisotropy of AMS data from the $\mathrm{E}$ (site 1) towards the $\mathrm{W}$ (sites 4 and 6) that points to higher strain and higher solid-state deformation in the vicinity of the western margin of the Blanice Graben, than along the eastern margin. Importantly, asymmetry of the gravimetric anomaly (Fig. 2) and alignment of gravity minima (NNE-SSW) suggest that the BMG was rooted/ intruded along the western margin of the Blanice Graben.

Sample SEV3 is the only exception to the above-described regional trends. Apparent inversion of the $\mathrm{k}_{1}$ and $\mathrm{k}_{3}$ maxima might be due to the presence (relics?) of cordierite in the studied sample. The cordierite is known to define an inverse magnetic fabric (Rochette et al. 1992), where $\mathrm{k}_{1}$ and $\mathrm{k}_{3}$ represent the pole of magnetic foliation and lineation, respectively. If this is true in our case, then SEV3 defines the same trend of magmatic foliation and lineation as the other samples. Cordierite forms spare phenocrysts in the DG. Its original presence in the BMG is indicated only by clusters of micas rimming rare cordierite relics (Janoušek et al. 2002). The SEV3 sample may thus represent less altered $\mathrm{BMG}$ granite.

The only mesoscopic indication of magmatic foliation we found in the BMG (site SEV2a), where biotite defines weak planar fabric (dip direction/dip: $170^{\circ} / 85^{\circ}$ ). This resembles the dip direction of magnetic foliation from site SEV6 $\left(354^{\circ} / 70^{\circ}\right)$ and SEV2a $\left(339^{\circ} / 60^{\circ}\right)$. There is, however, not enough data to discuss the extent of solidstate modification of the magmatic fabric.

\subsubsection{Early brittle deformation phase (oblique compression regime)}

Fault-slip data from the BMG at the Ševětín quarry indicate NW-SE oriented subhorizontal compression. The orientation of the minimum principal stress axis $\left(\sigma_{3}\right.$ : $277^{\circ} / 57^{\circ}$ ) is more or less similar to the maximum of the poles of $\mathrm{P}_{1}$ joints $\left(320^{\circ} / 47^{\circ}\right)$, which are extensional in nature. Similarly, most of the late magmatic dikes (aplite, leucogranite or pegmatite) also exhibit poles clustered tightly around the $\mathrm{P}_{1}$ maximum (Fig. 5a). The same holds for early hydrothermal quartz veins with minor tourmaline. All these data thus unambiguously indicate the long persistency of a minimum stress axis moderately inclined to the NW to W. The orientation of the maximum principal stress axis (slightly inclined to the SE) was favorable for oblique sinistral movements along the main faults of the Blanice Graben (Fig. 12b). Overall persistence of orientation of $\mathrm{P}_{1}$ joints across the whole studied area, compared to curved trends of magnetic foliations, may indicate that major oblique strike-slip movements along the faults of Blanice Graben occurred before formation of $\mathrm{P}_{1}$ joints.

\subsubsection{Mid-stage brittle deformation phase (strike-slip regime)}

This phase, which is mostly indicated by numerical analysis of the fault-slip data, points to subhorizontal N-S oriented compression and subhorizontal $\mathrm{E}-\mathrm{W}$ oriented extension (Fig. 12c). This is compatible with the orientation of $\mathrm{P}_{3}$ joints, as well as with the formation some the thin aplite dikes or the monomineral quartz veins (free of tourmaline/feldspar). Overall scarcity of hydrothermal veins coupled with this tectonic phase, however, indicates only a short-lived and relatively insignificant hydrothermal activity.

The magmatic activity ( $270 \pm 2 \mathrm{Ma}$; Košler et al. 2001) ascribed to this phase produced NNE-SSW to N-S trending and steeply dipping dikes of pyroxene-bearing microgranodiorite (Vrána et al. 1993) and quartz monzodiorite (Vrána and Janoušek 2006).

\subsubsection{Late brittle deformation phase (extension regime)}

Numerous fault-slip data indicate NNE-SSW oriented subhorizontal extension (Fig. 12d). The maximum of poles of late (quartz)-calcite (CC3) tension veins is shifted clockwise by c. $20-30^{\circ}$; however, it is still compatible with the stress axes calculated from the fault-slip data. The minor change in the strike of the $\mathrm{P}_{6}$ relative to the $\mathrm{P}_{5}$ joints most probably also reflects the clockwise rotation of the $\sigma_{1}$ and $\sigma_{3}$ stress axes. During this phase, the main 


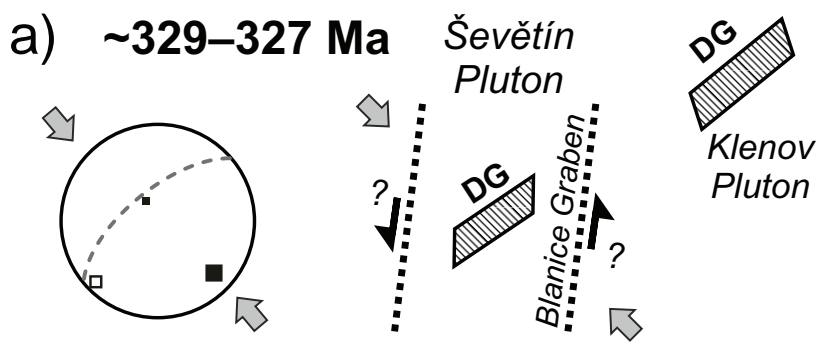

b) ( 305 Ma?)
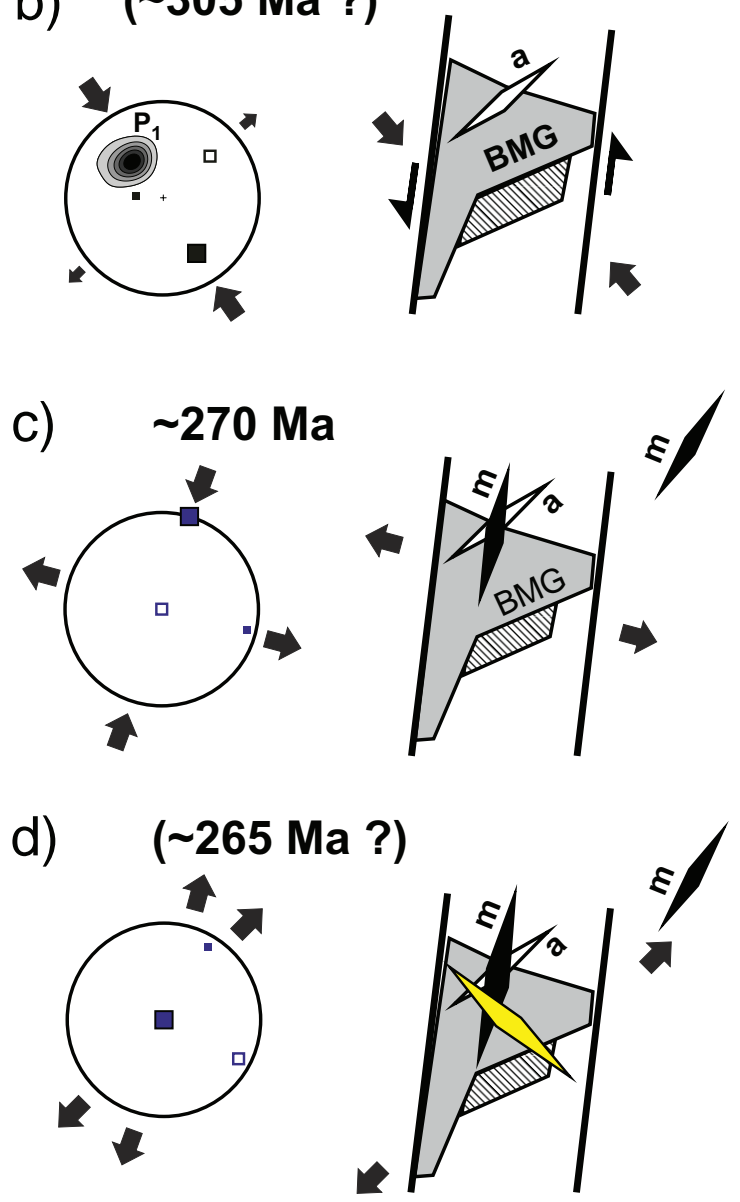

maximum principal stress axis

- intermediate principal stress axis

- minimum principal stress axis

Fig. 12 Schematic model of emplacement of the Ševětín Pluton in the context of evolution of the Blanice Graben: a - intrusion of the two-mica Deštná type granite under NW-SE oriented compression; b - intrusion of biotite-muscovite granite (BMG), followed by more or less coeval formation of extensional $\mathrm{P}_{1}$ joints and of aplitic dikes under oblique compression; $\mathbf{c}$ - strike-slip phase and late intrusion of the 270 Ma old pyroxene microgranodiorite dike into the relatively cool Ševětín Pluton; d - late extensional phase coupled with the formation NW-SE trending hydrothermal (quartz)-calcite veins with uneconomic $\mathrm{Pb}-\mathrm{Zn}$ ores.

stage of late hydrothermal activity occurred within the Blanice Graben, as indicated by the uneconomic $\mathrm{Pb}-\mathrm{Zn}$ ores (hydrothermal veins).

\section{Conclusions}

A structural study of the Ševětín Pluton (SP) enabled detailed reconstruction of the Blanice Graben tectonic evolution and of associated magmatic activity:

- The AMS study revealed steeply to moderately dipping planar magnetic fabrics that we interpreted mostly as solid-state in origin, especially in the vicinity of the Drahotěšice Fault (western margin of the Blanice Graben). Local preservation of original magmatic foliation is possible in the central to eastern parts of the SP. The overall sigmoidal trend of the magnetic fabrics indicates sinistral movements along the Blanice Graben fault systems postdating the intrusion of the biotite-muscovite granite (BTG) of the SP. This is further supported by well-defined subhorizontal magnetic lineation. The magnetic fabric of the SP is thus in sharp contrast to the subhorizontal metamorphic foliation and subhorizontal NW-SE trending stretching lineation in the surrounding Moldanubian host rocks.

- Paleostress and kinematic analysis of brittle structures allowed differentiation of three tectonic phases (oblique compression, strike-slip and extension), which postdated the intrusion of the BMG.

- The oblique compression phase comprised both the emplacement of the BMG and early stages of its brittle deformation. It was accompanied by the formation of NE-SW trending joints $\left(\mathrm{P}_{1}\right)$ and dikes (aplite), both dipping moderately to the SE.

- The strike-slip phase indicates more or less E-W trending extension and can be correlated with the intrusion of c. 270 Ma microgranodiorite dikes. The orientation of the stress axis was, however, unfavorable for the main movements on the major faults of the Blanice Graben.

- The extension phase was accompanied by the formation of hydrothermal $\mathrm{Pb}-\mathrm{Zn}-(\mathrm{Ag})$ quartz-carbonate veins and scarce $P_{5}$ and $P_{6}$ tension joints.

Acknowledgements. This paper was supported by the Grant Agency of Charles University (project No. 151810). We also greatly acknowledge the constructive reviews of P. Pitra and R. Grygar and the editorial comments of J. Žák and V. Janoušek.

Electronic supplementary material. List of the AMS data and of GPS coordinates of all studied sites is available online at the Journal web site (http://dx.doi.org/10.3190/ jgeosci.175).

\section{References}

AmBrož V (1935) Study on the metamorphic rocks between Hluboká and Týn nad Vltavou. Spisy prŕrodověd Fak Univ Karl 138: 1-44 (in Czech) 
Bankwitz P, Bankwitz E, Thomas R, Wemmer K, KämpF $H$ (2004) Age and depth evidence for pre-exhumation joints in granite plutons: fracturing during the early cooling stage of felsic rock. In: Cosgrove JW, Engelder T (eds) The Initiation, Propagation and Arrest of Joints and Other Fractures. Geological Society of London Special Publications 231: 25-47

Bouchez JL (1997) Granite is never isotropic: an introduction to AMS studies of granitic rocks. In: Bouchez JL, Hutton DHW, Stephens W (eds) Granite: From Segregation of Melt to Emplacement Fabrics. Kluwer Academic Publishers, Dordrecht, pp 95-112

Brandmayr M, Dallmeyer RD, Handler R, Wallbrecher E (1995) Conjugate shear zones in the Southern Bohemian Massif (Austria): implications for Variscan and Alpine tectonothermal activity. Tectonophysics 248: 97-116

Breiter K (2010) Geochemical classification of Variscan granitoids in the Moldanubicum (Czech Republic, Austria). Abh Geol B-A 65: 19-25

Cordier P, Vrána S, Doukhan JC (1994) Shock metamorphism in quartz at Ševětín and Sušice (Bohemia)? A T.E.M. investigation. Meteoritics 29: 98-99

ČTVRTNík J, PAVLíčEK V (2002) Occurrence of colored sphalerite at Ševětín. Minerál 10: 9-12 (in Czech)

Čuta J, Manová M, ŠAlanský K (1975) Explanations to geophysical map 1:25 000, sheet 22-444 Ševětín. Unpublished report, Geofyzika Brno, Prague, pp 1-22 (in Czech)

Dallmayer RD, Franke W, Weber K (eds) (1995) PrePermian Geology of Central and Eastern Europe. Springer-Verlag, Berlin, pp 1-604

FAURE M. (1995) Late orogenic Carboniferous extensions in the Variscan French Massif Central. Tectonics 14: 132-153

Fiala J, Fuchs G., Wendt J.I. (1995) VII.C.1 Stratigraphy. In: Dallmeyer RD, Franke W, Weber K (eds) Pre-Permian Geology of Central and Eastern Europe. Springer-Verlag, Berlin, pp 417-428

Finger F, Gerdes A, Janoušek V, René M, Riegler G (2007) Resolving the Variscan evolution of the Moldanubian sector of the Bohemian Massif: the significance of the Bavarian and the Moravo-Moldanubian tectonometamorphic phases. J Geosci 52: 9-28

Finger F, René M, Gerdes A, Riegler G (2009) The SaxoDanubian Granite Belt: magmatic response to postcollisional delamination of mantle lithosphere below the southwestern sector of the Bohemian Massif (Variscan Orogen). Geol Carpathica 60: 205-212

FraněK J, Schulmann K, Lexa O, Tomek C, Edel JB (2011) Model of syn-convergent extrusion of orogenic lower crust in the core of the Variscan belt: implications for exhumation of high-pressure rocks in large hot orogens. J Metamorph Geol 29: 53-78

FrANKE W (2000) The mid-European segment of the Variscides: tectonostratigraphic units, terrane boundaries and plate tectonic evolution. In: FrANKE W, HAAK V, ONCKEN
O, TAnner D (eds) Orogenic Processes, Quantification and Modelling in the Variscan Belt. Geological Society of London Special Publications 179: 35-61

Friedl G, von Quadt A, Frasl G, Finger F (1992) Neue $\mathrm{U} / \mathrm{Pb}$ Altersdaten aus der südlichen Böhmischen Masse. Frankfurter Geowiss Arb A11: 217-218 (in German)

Friedl G, von Quadt A, Frasl G, Finger F (1996) Timing der Intrusionstätigkeit im Südböhmischen Batholith: 6. Symposion Tektonik-Strukturgeologie-Kristallingeologie, Salzburg, 10-15 April 1996. Fakultas Universitätsverlag, Vienna, pp 127-130 (in German)

Friedl G, Cooke RA, Finger F, McNaughton NJ, Fletcher IR (2011) Timing of Variscan HP-HT metamorphism in the Moldanubian Zone of the Bohemian Massif: U-Pb SHRIMP dating on multiply zoned zircons from a granulite from the Dunkelsteiner Wald Massif, Lower Austria. Mineral Petrol 102: 63-75

Gerdes A (2001) Magma homogenization during anatexis, ascent and/or emplacement? Constraints from the Variscan Weinsberg Granites. Terra Nova 13: 305-312

Gerdes A, Wörner G, Henk A (2000) Post-collisional granite generation and HT-LP metamorphism by radiogenic heating: the Variscan South Bohemian Batholith. J Geol Soc, London 157: 577-587

Gerdes A, Friedl G, Parrish RR, Finger F (2003) High-resolution geochronology of Variscan granite emplacement - the South Bohemian Batholith. J Czech Geol Soc 48: 53-54

Holub V (2001) The occurrences of the Permo-Carboniferous sequences in the Blanice Graben. In: PEŠEK J, HoluB V, Jaroš J, Malý L, Martínek K, Prouza V, Spudil J, TÁSLER R (eds) Geology and Deposits of Upper Paleozoic Limnic Basins of the Czech Republic. Czech Geological Survey, Prague, pp 197-207 (in Czech)

Holub FV, KLEČKa M, MatĚJKa D (1995) Igneous activity. In: Dallmeyer RD, Franke W, Weber K (eds) Pre-Permian Geology of Central and Eastern Europe. Springer-Verlag, Berlin, pp 444-452

HroudA F, KaHAN Š (1991) The magnetic fabric relationship between sedimentary and basement nappes in the High Tatra Mountains, N. Slovakia. J Struct Geol 13: 431-442

JANOUŠEK V, HoLUB FV (2007) The causal link between HPHT metamorphism and ultrapotassic magmatism in collisional orogens: case study from the Moldanubian Zone of the Bohemian Massif. Proc Geol Assoc 118: 75-86

JANOUŠEK V, VRÁNA S, ERBAN V (2002) Petrology, geochemical character and petrogenesis of a Variscan post-orogenic granite: case study from the Ševětín Massif, Moldanubian Batholith, Southern Bohemia. J Czech Geol Soc 7: 1-22

JELÍNEK V (1981) Characterization of the magnetic fabric of rocks. Tectonophysics 79: T63-T67

Kadlec E, OdstrčIl J, Šalanský K (1978) Summary Processing of Geophysical Data from the South-Bohemian Basins Area. Unpublished report, Geofyzika Brno, Prague, pp 1-175 (in Czech) 
KLEČKA M, MatĚJKa D (1996) Moldanubian Batholith - an example of the evolution of the Late Paleozoic granitoid magmatism in the Moldanubian Zone, Bohemian Massif (Central Europe). In: Srivastava RK, Chandra R (eds) Magmatism in Relation to Diverse Tectonic Settings. Oxford and IBH Publishing Co., New Delhi, pp 353-373

KlečKa M, MatěJKa D, Jalovec J, VaňKová V (1991) Geochemical research of a granitoid group of the Eisgarn type in the S part of the Central Massif of the Moldanubian Pluton. Zpr geol výzk v roce 1989, 109-111 (in Czech)

KoŠLER J, Kelley SP, VRÁNA S (2001) ${ }^{40} \mathrm{Ar} /{ }^{39} \mathrm{Ar}$ hornblende dating of a microgranodiorite dyke: implications for early Permian extension in the Moldanubian Zone of the Bohemian Massif. Int J Earth Sci (Geol Rundsch) 90: 379-385

MALAVIEILle J (1993) Late orogenic extension in mountain belts: insights from the Basin and Ranges and the Late Paleozoic Variscan Belt. Tectonics 12: 1115-1130

MATĚJKA D (1991) Geochemical and Petrological Characteristics of Rocks of the Moldanubian Zone South of Veselí nad Lužnicí: A Relationship Between the Ševětín Granodiorite and Rocks of The Eisgarn Type. Unpublished Ph.D. thesis, Charles University, Prague, pp 1-148 (in Czech)

MATĚJKA D, JANOUŠEK V (1998) Whole-rock geochemistry and petrogenesis of granites from the northern part of the Moldanubian Batholith (Czech Republic). Acta Univ Carol, Geol 42: 73-79

MatěJKa D, Nosek T, René M (2003) Petrogenesis of twomica granites of the Ševětín Massif. Mitt Österr Miner Ges 148: 359-371

Matte P, Maluski H, Echtler H (1985) Variscan eastward ductile shearing in the Waldviertel nappes (South eastern Bohemian Massif, Austria) $-{ }^{39} \mathrm{Ar} /{ }^{40} \mathrm{Ar}$ data. Compt Rend Acad Sci serie II 301: 721-726

Medaris LG, Wang H, Jelínek E, Mihaljevič M, Jakeš P (2005) Characteristics and origins of diverse Variscan peridotites in the Gföhl Nappe, Bohemian Massif, Czech Republic. Lithos 82: 1-23

Nagata T (1961) Rock Magnetism. Maruzen, Tokyo, pp 1-350

Racek M, Štípská P, Pitra P; Schulmann K, Lexa O (2006) Metamorphic record of burial and exhumation of orogenic lower and middle crust: a new tectonothermal model for the Drosendorf Window (Bohemian Massif, Austria). Mineral Petrol 86: 221-251

René M, MatĚJKa D, KLEČKA M (1999) Petrogenesis of granites of the Klenov Massif. Acta Montana 113: 107-134

Rochette P, Jackson MJ, Aubourg C (1992) Rock magnetism and the interpretation of anisotropy of magnetic susceptibility. Rev Geophys 30: 209-226

Schulmann K, Lexa O, Janoušek V, Lardeaux JM, Edel JB (2014) Anatomy of a diffuse cryptic suture zone: an example from the Bohemian Massif, European Variscides. Geology 42: 275-278

Suk M, Dornič J, Hokr Z, Holásek O, Holub V, Líbalová J, Odehnal L, Sattran V, Šalanský K, Zima K, Žebera K
(1978) Explanations to the general geological map of the ČSSR $1: 25$ 000, sheet 22-444 Ševětín. Czech Geological Survey, Prague, pp 1-65 (in Czech)

ŠALANSKÝ K (1981) Explanations to geophysical map $1: 25$ 000, sheet 22-442 Dolní Bukovsko. Unpublished report, Geofyzika Brno, Prague, pp 1-16 (in Czech)

Verner K, ŽÁk J, Šrámek J, Paclíková J, ZavŘelová A, MACHEK M, FINGER F, JOHNSON K (2014) Formation of elongated granite-migmatite domes as isostatic accommodation structures in collisional orogens. J Geodyn 73: 100-117

VRÁNA S (1987) The Ševětín astrobleme, southern Bohemia, Czechoslovakia. Geol Rdsch 76: 505-528

VRÁNA S, BÁRTEK J (2005) Retrograde metamorphism in a regional shear zone and related chemical changes: the Kaplice Unit of muscovite-biotite gneisses in the Moldanubian Zone of southern Bohemia, Czech Republic. J Czech Geol Soc 50: 43-57

VRÁNA S, JANOUŠEK V (2006) Late-orogenic Variscan magmatism: the case of quartz monzodiorite dykes from the Blanice Graben, southern Bohemia. J Czech Geol Soc 51: 231-248

Vrána S, Bendl J, Buzek F (1993) Pyroxene microgranodiorite dykes from the Ševětín structure, Czech Republic: mineralogical, chemical and isotopic indication of a possible impact melt origin. J Czech Geol Soc 38: 129-148

VRÁNA S, SlabÝ J, BendL J (2005) The Kaplice dyke swarm of biotite granodiorite porphyry and its relationship to the Freistadt granodiorite, Moldanubian Batholith. J Czech Geol Soc 50: 9-17

WELSER P, ZiKeš J (2009) Minerals from the Ševětín quarry. Minerál 17: 326-334 (in Czech)

ZACHARIÁš J, HÜBST Z (2012) Structural evolution of the Roudný gold deposit, Bohemian Massif: a combination of paleostress analysis and review of historical documents. J Geosci 57: 87-103

ZACHARIÁŠ J, ŠTRBA M (2014, in print) Evolution of brittle deformations in the granite from the quarry at Ševětín near České Budějovice and their relationship to formation of $\mathrm{Pb}-\mathrm{Zn}$ ores. Sbor Jihočes Muz (Čes Budějovice), přír Vědy 54: (in Czech)

Zachariáš J, Frýda J, Paterová B, Mihaljevič M (2004) Arsenopyrite and As-bearing pyrite from the Roudný deposit, Bohemian Massif. Mineral Mag 68: 31-46

Zachariáš J, Paterová B, Pudilová M (2009) Mineralogy, fluid inclusion, and stable isotope constraints on the genesis of the Roudný $\mathrm{Au}-\mathrm{Ag}$ deposit, Bohemian Massif. Econ Geol 104: 53-72

Žák J, Verner K, Finger F, Faryad SW, Chlupáčová M, VeselovskÝ F (2011) The generation of voluminous S-type granites in the Moldanubian unit, Bohemian Massif, by rapid isothermal exhumation of the metapelitic middle crust. Lithos 121: 25-40

ŽAlOHAR J, VRABEC M (2007) Paleostress analysis of heterogeneous fault-slip data: the Gauss method. J Struct Geol 29: 1798-1810 